
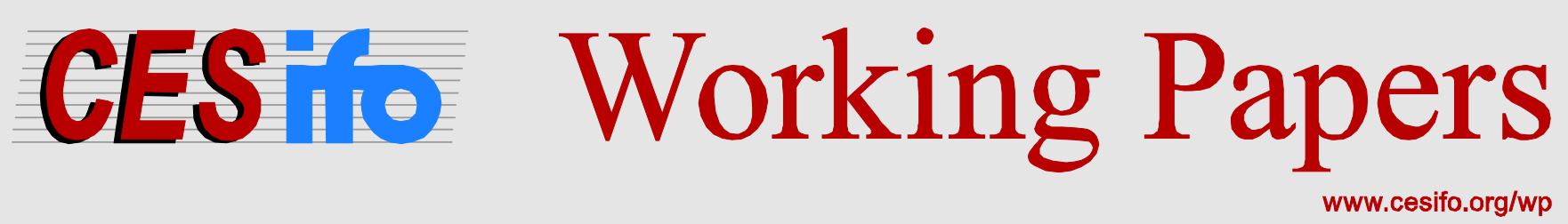

\title{
First Impressions: \\ How Leader Changes Affect Bilateral Aid
}

\author{
Tobias Rommel \\ Paul Schaudt
}

\author{
CESIFO WORKING PAPER NO. 6047 \\ CATEgory 2: Public CHOICE \\ ORIGINAL VERSION: AUGUST 2016 \\ THIS VERSION: SEPTEMBER 2017
}

An electronic version of the paper may be downloaded

- from the SSRN website:

- from the RePEc website:

- from the CESifo website:

WWW.SSRN.com

Www.RePEc.org

www.CESifo-group.org/wp 


\title{
First Impressions: How Leader Changes Affect Bilateral Aid
}

\begin{abstract}
This paper investigates a new mechanism to explain politically induced changes in bilateral aid. We argue that shifts in the foreign policy alignment between a donor and a recipient country following leadership changes induce reallocation of aid. This is due to heightened uncertainty of recipients' behavior in the international arena. Utilizing data from the G7 and 133 developing countries between 1975 and 2012 and employing gravity and control function models, we show that incoming leaders in recipient countries, which politically converge towards their donors, receive more aid commitments, compared to those that diverge. Additionally, accounting for donor leader change, we find that incumbent recipient leaders have an opportunity to get even more aid when political change in donor countries moves them closer to the donor's foreign policy position. Thus, leadership turnover in recipient and donor countries makes otherwise inconsequential deviations in foreign policy alignment highly consequential for aid provision.
\end{abstract}

JEL-Codes: D720, F350, F530, O190.

Keywords: dyadic leader change, UNGA voting realignment, development aid.

Tobias Rommel

Department of Political Science

University of Zurich

Zurich / Switzerland

rommel@ipz.uzh.ch
Paul Schaudt

Institute of Macroeconomics

University of Hannover

Hanover / Germany

schaudt@glad.uni-hannover.de

We thank Richard Bluhm, Axel Dreher, Martin Gassebner, Krisztina Kis-Katos, Tommy Krieger, Mariana Lopes da Fonseca, Erasmus Kersting, Christopher Kilby, Christoph Mikulaschek, Sibel Oktay, Ari Ray, Stefanie Walter, Wen-Chin Wu, as well as participants at the CESifo Workshop on Political Economy (Dresden, 2015), the Annual Conference on the Political Economy of International Organizations (Salt Lake City, 2016), the Annual Meeting of the European Public Choice Society (Freiburg, 2016), the Annual Conference of the Midwest Political Science Association (Chicago, 2016), the Annual International Conference of the Research Group on Development Economics of the German Economic Association (Heidelberg, 2016), and the Workshop of the Silvaplana Political Economy Group (Pontresina, 2016) for valuable comments. 


\section{Introduction}

Official development aid (ODA) is an important source of financial liquidity for developing countries. If funds run dry, these countries face severe economic repercussions. As aid is not exclusively granted on need, both the size and the volatility of aid flows are subject to politics. Long-term relations, such as colonial ties or geopolitical considerations (e.g., Alesina and Dollar, 2000; Collier and Dollar, 2002) and short-term shifts in the political importance of recipients, such as membership in the United Nations Security Council (UNSC) (e.g., Kuziemko and Werker, 2006; Dreher et al., 2009a,b), affect bilateral ODA flows. Apart from a recipient's international standing, its political positions matter as well. Disagreement between donors and recipients on policies significantly lowers aid flows, especially if issues are highly relevant for donors (Andersen et al., 2006; Dippel, 2015; Vreeland and Dreher, 2014). Donors even adjust access to liquidity strategically in order to influence elections in recipients countries. They increase bilateral aid to political friends during election years, thereby bolstering re-election prospects, while they decrease aid to political opponents (Faye and Niehaus, 2012). ${ }^{1}$ Given the fact that donors try to use aid to keep their friends in power and actively foster political change in hostile countries, it is surprising that we know only little about the impact of leadership turnover on aid allocation: how do donors adjust aid provision following leader change?

Our paper proposes an answer to this question. Leadership turnover - in both recipient as well as donor countries - is a source of uncertainty concerning future behavior in the international arena. Since the pursuit of foreign policy is usually the prerogative of the executive branch, leader change opens the door for large-scale policy shifts. As the potential for policy change is high, re-alignment can go in both directions. New leadership does not automatically guarantee improved bilateral relations between donors and recipients. Therefore, the consequences of leader change for aid allocation are ambiguous ex ante. We argue that donors take foreign policy positions announced by recipients under increased scrutiny. Shifts in foreign policy following leader change work as an important

\footnotetext{
${ }^{1}$ Similarly, the United States use their weight in the International Monetary Fund to provide loose conditions on credits (Dreher and Jensen, 2007) and in the World Bank to provide quicker loan disbursement (Kersting and Kilby, 2016) for political friends in the run-up to elections.
} 
source of information on which donors base their decisions regarding aid allocation. What is more, we argue that the effect of political re-alignment on aid allocation is not only present in case of leadership change in recipient countries, but is also consequential following leadership change in donor countries. Given that political relationships between states are reciprocal, changes in the head of executive of donor countries similarly increase uncertainty by discounting past behavior and therefore expectations about future relations. Hence, new donor leaders base aid disbursement on the foreign policy changes of recipient country governments. We expect that sizable reallocations of development aid occur after either recipient or donor leader change. Yet, the direction should depend on the foreign policy shifts of recipient countries towards donors. Leaders who signal political accord receive more aid; countries receive less aid if a leader signals political animosity.

Canada, for instance, takes recipients' foreign policy positions into account when it comes to aid provision. The Canadian International Development Agency (CIDA) explicitly states that they base aid disbursement on recipients' "needs, their capacity to manage development programs, and their alignment with Canadian foreign policy priorities" (CIDA, 2010, 3). In line with this notion, Ghana has always received sizable amounts of aid from Canada (Global Affairs Canada, 2015), but experienced a sharp decrease in 2009. Interestingly, this drop coincides with a change in leadership following the 2008 general elections. John Atta Mills defeated Nana Akufo-Addo in the second round run-off election held on December 28, 2008 by a margin of about $.5 \%$ and was declared president on January 3, 2009. Uncertainty was high about the leadership's policy positions, which was further increased by the fact that Atta Mills had distanced himself from his mentor, former president Jerry Rawlings, during the campaign (Encyclopaedia Britannica, 2017). More importantly, alignment in the United Nations General Assembly between Canada and Ghana decreased by about 7 percentage points, indicating less support for Canada's foreign policy stance, which in turn resulted in aid cuts.

We rely on comparable measures of voting alignment in the United Nations General Assembly (UNGA) to capture shifts in foreign policy (Voeten, 2000). Voting in international organizations is a very cost-effective way for donors to observe political alignment 
or dis-alignment of their recipients. Accordingly, UNGA voting patterns have frequently been used to proxy for political closeness between countries (e.g., Thacker, 1999; Barro and Lee, 2005; Bailey et al., 2015). Indeed, studies suggest that changes in heads of executive make a decisive difference when it comes to foreign policy proximity (Dreher and Jensen, 2013; Mattes et al., 2015). Yet, research has focused exclusively on either leadership changes in recipient countries only, or monadic position changes. We assert that leader changes in both recipient and donor countries affect bilateral relations and, consequently, aid allocation.

This study scrutinizes the effect that a change in voting alignment has on aid commitments. We focus on alignment changes that occur after leadership change in a dyadic donor-recipient leader pair, between leaders from the $\mathrm{G}^{2}$ and 133 developing countries from 1975 to 2012. Employing gravity and control function models, we show that yearly alterations of foreign policy alignment have no significant effect on aid commitments, unless occurring after leadership turnover. In line with our argument, the adjustment of foreign policy objectives after leader changes has a tremendous impact on aid commitments. Donors reward political convergence and punish divergence. These effects are different in substantial terms. Our findings suggest that leader changes in donor countries represent a 'window of opportunity' that recipients can use to attract gains in development aid, while recipient leader changes open predominantly a 'window of dis-opportunity' to forgo aid cutbacks. Focusing exclusively on monadic leadership changes in recipient countries is not able to capture this essential variation in the allocation of aid induced by leadership changes. Taken together, recipient country leaders have to decide early on, how to align themselves with their international aid providers, as first impressions matter a great deal.

We proceed as follows: Section 2 presents our theoretical argument linking dyadic leadership change, political alignment, and aid allocation. Section 3 describes the data. Section 4 discusses our empirical strategy and results. Section 5 presents robustness tests. Section 6 concludes.

\footnotetext{
${ }^{2}$ Canada, France, Germany, Italy, Japan, United Kingdom and United States
} 


\section{Leader Change and Aid}

Donor countries have vested interests in political alignment with developing countries and thus care about which recipient leader is in power (Dreher and Jensen, 2007; Faye and Niehaus, 2012). Yet, leadership turnover in recipient countries increases uncertainty about future behavior in international politics as it sets the stage for new foreign policy agendas. Because a new leader in a recipient country has the potential to change bilateral relations, the leader in a donor country faces increasing uncertainty about the behavior of the recipient leader in the aftermath of leadership change, thus endangering donors' vested interests. Hence, donors might have to reevaluate the current financial support they provide to a recipient country. ${ }^{3}$

After inauguration, a new recipient country government can adjust its foreign policy towards the donors in three ways: keep relations unchanged, converge towards a common ideal position on international issues, or diverge. As a reaction to changes in political alignment, we argue that a donor country in turn possesses two options to alter its development cooperation: reward political friends with external revenues or deprive opponents of political and economic benefits. Given that donors have an incentive to bind new leaders early on, they have a rationale to reward them with additional aid. To the contrary, donors hamper new recipient leaders by cutting aid if they perceive them as hostile.

Whether a country under new leadership is a political friend or foe is difficult to evaluate in advance. Relying on ex ante characteristics, such as the foreign policy stances of leaders in the run-up to elections, may provide only an incomplete picture of an administration's foreign policy agenda. Past observed behavior should be heavily discounted as governments have private information that shape their foreign policy preferences as well as incentives to conceal their true intentions (e.g., Fearon, 1995, 1997). Additionally, audience costs change in conjunction with leadership turnover, effectively altering incentive structures for the leader after an election. ${ }^{4}$ Lastly, the new leader may only imperfectly be

\footnotetext{
${ }^{3}$ Incoming political leaders have a wide range of effects, for instance regarding trade (McGillivray and Smith, 2004), economic growth (Jones and Olken, 2005), or democratization (Jones and Olken, 2009).

${ }^{4}$ Arguably, a sitting leader wants to stay in power and is internally constrained by his domestic support groups (Moravcsik, 1997; Putnam, 1988; Bueno de Mesquita et al., 2003).
} 
bound to path-dependency or even have come to power by opposing the existing policy platform. Hence, the reaction of the donor hinges on the ex post conduct of the new leadership in the recipient country.

We argue that donor countries observe the behavior of new recipient country leaders during their first year in office, for example via voting alignment in the UNGA. Such votes cover a wide array of issues that allow political actors to estimate alignment tendencies and are thus a "record of how the state wants to be seen by others, the international norms it finds acceptable, and the positions it is willing to take publicly" (Mattes et al., 2015, 283). Voting in line with (or against) a donor's interests thus constitutes a cost effective source of information that the donor can observe and use to determine if the other leader is more likely to be a friend or foe in the future. Thus, the initial trajectory of foreign relations should matter for the amount of political side payments the donor chooses to make (Kuziemko and Werker, 2006; Bueno de Mesquita and Smith, 2010). ${ }^{5}$ Summing up, leadership change itself should not necessarily alter the allocation decision of the donor. Rather, the donor's willingness to provide ODA is shaped by the initial foreign policy positions that a new recipient leader takes.

H1: The effect of recipient country leadership change on aid flows is conditional on the political alignment new leaders establish towards their donor during their first year in power. Alignment with the donor increases aid flows; dis-alignment decreases aid flows.

Nevertheless, the very nature of political alignment is reciprocal. Therefore, the importance of foreign policy realignment does not solely originate from recipient country leadership changes. If a donor country leader enforces a new set of foreign policy objectives, its repercussions influence a recipient country's ability to pursue and implement its own policy goals. In other words, leadership changes in donor countries themselves shape bilateral foreign policy proximity. Thus, the pursuit of foreign policy goals is further confined by external constraints that arise from the behavior and power of other countries. In essence, both leaders matter for bilateral relations between countries. What is more,

\footnotetext{
${ }^{5}$ Note, that such 'signaling' information becomes even more important if there is no prior observable behavior of an actor.
} 
reacting to changes in donor countries might be in the interest of recipient countries. Internal constraints are fixed in the short run. Leaders are usually not able to change their support group - the electorate in democracies or the selectorate in autocracies - because the associated costs endanger their hold on power. Changes in the donor's foreign policy that emanate from leadership change thus open a window of opportunity for recipient countries to change bilateral relations, as external constraints on foreign policy decrease.

Consider that newly elected US presidents attempt to accomplish international success rather quickly. Barack Obama, for example, vowed to reset relations with the Middle East and reduce US interference in his Cairo speech, held shortly after his 2009 inauguration (New York Times, 2009). Donor leaders consider the reactions from the developing world as approval or dis-approval. A recipient country can either show willingness to work together or take a stance and openly oppose the new foreign policy agenda of the donor. In this sense, a change in donor leadership can provide other countries with the opportunity to reset relations or withdraw loyalty, respectively. If leaders welcome a new president and signal that they will work with them, they receive additional aid as part of a charm offensive. If a new leader in a donor country receives hostile signals from a recipient country's political leadership, aid flows decrease. In both cases we argue that first impressions matter a great deal and should influence the allocation of aid.

H2: Recipient country convergence towards a donor's foreign policy position after donor country leadership change increases aid flows; divergence decreases aid flows.

Leadership changes in both the recipient and the donor country reset personal relationships between and domestic constraints on leaders opening windows of opportunity to fundamentally change foreign policy. In such situations, uncertainty in the bilateral relations between a donor and a recipient country rises and donor leaders make aid allocation decisions depending on ex post changes in foreign policy positions of recipient countries. Because donor countries have vested interests in political alignment, they reward political alignment and punish dis-alignment. 


\section{Data and Operationalization}

Our dependent variable is official development aid. In line with Faye and Niehaus (2012), we use ODA commitments in instead of disbursements, ${ }^{6}$ since disbursements in a given year might originate from projects granted earlier. Commitments on the other hand are targeted to a specific country in a given year. Hence, we can directly link them to shifts in political alignment between countries following leadership turnover. We take ODA commitments from the Development Action Committee (DAC) database of the OECD (2015). ${ }^{7}$ Because aid commitments are highly skewed, we use log-transformed values. We focus mainly on country dyads with positive aid flows to avoid arbitrary logtransformations. Nevertheless, we control for the inclusion of zeros as well as for selection effects in the robustness section. ${ }^{8}$

Our first independent variable is leadership change. We use data from the updated Archigos dataset (Goemans et al., 2009) to identify the heads of executive of each recipient and donor country. We code a change in leadership if the leader of country $i$ in year $t$ differs from the leader of country $i$ in year $t-1$. If several leaders were in power in a country during a given year, we focus on the leader that has spent the highest fraction of days in office over the course of the respective year. As such, we assume that more days in office increase the capacity of a country leader to shape foreign policy within

\footnotetext{
${ }^{6}$ Our commitments are measured in millions of constant 2013 US\$.

${ }^{7}$ ODA is defined as those "flows to countries and territories on the DAC list of ODA recipients and to multilateral institutions which are: i. provided by official agencies, including state and local governments, or by their executive agencies; and ii. each transaction of which: a) is administered with the promotion of the economic development and welfare of developing countries as its main objective; and b) is concessional in character and conveys a grant element of at least 25 per cent (calculated at a rate of discount of 10 per cent)" (OECD, 2015). Over the years the DAC has refined the ODA reporting rules to ensure accuracy and consistency among donors. The boundary of ODA has been carefully delineated, including: 1. Military aid: No military equipment or services are reportable as ODA. Anti-terrorism activities are also excluded. The cost of using donors' armed forces to deliver humanitarian aid is eligible. 2 . Peacekeeping: Most peacekeeping expenditures are excluded in line with the exclusion of military costs. Some closely defined developmentally relevant activities within peacekeeping operations are included. 3 . Nuclear energy: Reportable as ODA, provided it is for civilian purposes. 4. Cultural programs: Eligible as ODA if they increase cultural capacities, but one-off tours by donor country artists or sportsmen, and activities to promote the donors' image, are excluded.
}

${ }^{8}$ Note that $23 \%$ of the bilateral aid flows are zero. This is mainly driven by the complete absence of development cooperation between Japan and several developing countries. 
a given year. ${ }^{9}$ Assuming that foreign policy is 'high politics' and primarily influenced by the person running the executive branch, we define the head of the executive as the country leader. In a next step, we use information on leadership changes in recipient and donor countries to construct dyadic leader changes. Our units of analysis are leader dyads. To illustrate this approach, consider that former President Barack Obama and former President Dilma Rousseff had formed the dyad between the United States and Brazil until May 12, 2016, until she was replaced by Michael Temer. ${ }^{10}$

Our analysis includes 133 recipient countries (see Table A-1) that - in tandem with the G7 donor countries - form 686 country dyads that engage in development cooperation over the 1975-2012 period. The panel is unbalanced since some recipient countries enter after 1975. Similarly, some donors only engage in development cooperation with a selected set of recipients. Given these limitations, our dataset includes 7505 donor-recipient-leaderpairs and 5010 dyadic leader changes. The median leader dyad lasts about five years. By construction, the shortest period is one year. The most durable leader dyads are between Germany under Chancellor Helmut Kohl and several recipient countries with a duration of 16 years; the exact time Kohl was in office. All G7 countries form administration dyads lasting longer than 10 years, with the exception of the United States, due to presidential term limits.

The second independent variable is the change in foreign policy alignment between countries. We proxy changes of bilateral relations, using voting alignment in the United Nations General Assembly. Focusing on the UNGA has several advantages: data availability is generally very high because all sovereign countries have voting rights. Votes in the UNGA furthermore cover a wide array of issues that allow to proxy general alignment tendencies instead of ad hoc political liaisons (Mattes et al., 2015). Voting alignment has thus often been used to proxy political closeness. We measure voting alignment changes as the difference in the percentage of common yes and no votes between any two countries

\footnotetext{
${ }^{9}$ This approach differs from Mattes et al. (2015) who use information on the leader who is in power in December for the entire year.

${ }^{10}$ Note that we would code a change for 2016 since Michael Temer has occupied more days in office than Dilma Rousseff. If he would have stepped down early and another person would have held office also for a shorter time than Mrs. Rousseff, we would have coded the change in 2017.
} 
in one administration dyad between $t-1$ and $t$ (Thacker, 1999; Faye and Niehaus, 2012). The data is provided by Voeten et al. (2009). Although this difference ranges empirically from -94 to +67 percentage points, such radical changes in bilateral relations are rather uncommon (Voeten, 2004; Hillman and Potrafke, 2015). Nevertheless, we test whether our results are sensitive to radical changes by restricting the scope of the alignment change in the robustness section. In addition, we make use of different measures that also include vote abstentions (Barro and Lee, 2005). Note also that Häge and Hug (2016) show that UNGA affinity scores are sensitive to the inclusion of consensus votes that systematically increase voting alignment between all country pairs. As we use changes in voting alignment, this should not affect our measure if the number of consensus votes does not change dramatically from year to year. In the main models, we use all votes since general foreign policy preferences are arguably more reliably revealed by all votes, as compared to only important votes (Andersen et al., 2006). Nonetheless, we test the robustness of our results and also include regular votes - votes that reoccur over UNGA sessions - and key votes (Kilby, 2009; Kersting and Kilby, 2016).

To isolate initial changes in foreign policy alignment from general long- and shortterm alignment or dis-alignment tendencies between donor and recipient over time, we further include two variables into our baseline specification: in line with Faye and Niehaus (2012), we control for alignment between the former recipient and donor leader. For this we use average alignment over the past administration dyad instead of recipient leader dyads. This limits the maximum average alignment to 16 years, whereas Faye and Niehaus (2012) have cases where the alignment is averaged over nearly their entire sample period. For instance, Muammar al-Gaddafi ruled Libya from 1977 to 2011 and essentially covered the whole spectrum of political relationships with several G7 countries over those years. We argue that our dyadic measure of past alignment is better able to capture past alignment because it does not blur the current relations by relations from decades ago that, in addition, were established by other administrations in donor countries. The effect of past mean alignment thus captures how well the previous administration dyad has worked with each other and explains path dependency in current bilateral relations. 
Moreover, we also include the lagged alignment level since it mechanically determines the possible range of re-alignment between $t$ and $t-1$. Descriptive statistics of all variables used in the study are reported in Table A-2, sources and definitions in Table A-3.

\section{Empirical Strategy and Findings}

In our baseline specification (see Equation 1) we regress the natural logarithm of ODA commitments at time $t$ between the leader pair of donor country $j$ to recipient country $i$ on dyadic leader change, alignment changes and their interaction. The alignment change is defined as the difference in common votes between two countries from $t-1$ to $t$. The coefficient of interest is the interaction between leader change and changes in voting alignment, i.e. the corresponding change in voting alignment in the UNGA from $t-1$ (the last year of the outgoing leader in either one of the two countries) to $t$ (the first year of the new leader in either one of the two countries). We expect a positive interaction effect of $\theta$ implying that alignment following a change in leadership increases aid flows, while disalignment decreases aid flows. $\phi$ captures the effect of the lagged alignment. As such, it controls for the recent past of UNGA alignment in a dyad $d$, which determines the possible range of the change in voting alignment. $\psi$ controls for the past mean alignment of the previous administration dyad, to capture the overall relations between the two countries. $\eta$ is a vector including a set of additional donor and recipient control variables, such as GDP and population. $\alpha_{i j}$ are donor-recipient fixed effects capturing unobserved timeinvariant heterogeneity for specific country dyads. Additionally, $\gamma_{t}$ are year fixed effects to control for any global shocks that simultaneously affect alignment, leader change and aid commitments across all countries.

$$
\begin{aligned}
\operatorname{lnODA}_{i j t}= & \beta \cdot \text { leader }_{i j t}+\delta \cdot \text { alignment }_{i j t}+\theta \cdot \text { leader }_{i j t} \cdot \text { alignment }_{i j t} \\
& +\phi \cdot \text { alignment }_{i j t-1}+\psi \cdot \text { meanalignment }_{i j d-1}+\mathbf{X}_{i j t}^{\prime} \boldsymbol{\eta}+\alpha_{i j}+\gamma_{t}+\epsilon_{i j t}
\end{aligned}
$$

Table 1 displays the results of this empirical strategy, when phasing in the different components of the regression model. Column 1 only includes dyadic leadership change. It 
shows that there is no unconditional effect of leadership turnover on ODA commitments from donor to recipient in a given donor-recipient pair; $\beta$ is not statistically significant. Hence, the pooled leader change effect from either recipient or donor country does not affect aid allocation in a systematic way. In column 2, we only include the yearly change of voting alignment in the UNGA. The statistically significant positive effect highlights that convergence induces more aid. In column 3, we include our main independent variable - the interaction between changes in political alignment and leadership change. Dyadic leader changes with constant bilateral relations as well as yearly fluctuations in alignment in years without leadership turnover are both statistically insignificant. To the contrary, the interaction term is, as expected, positive and statistically significant. Voting convergence after either a donor or a recipient leader change is rewarded with more ODA commitments, while divergence is punished with aid cutbacks. Thus, the significant unconditional convergence effect is solely due to alignment changes after leader change. These findings show that leadership turnover itself does not change aid allocation patterns. Change in leadership only becomes consequential if it simultaneously changes the trajectory of foreign relations between countries.

In column 4, we further exploit the dyadic structure of our data by employing donor-recipient-pair, donor-year and recipient-year fixed effects. This gravity-like approach (Head and Mayer, 2014) enables us to control for other factors that vary on either donor or recipient countries over time and explain ODA allocation. Hence, unobserved heterogeneity is reduced to variables that vary within the dyads over time and are not explained by variables varying over donor and recipient by year, such as GDP or population size. A further benefit of this approach is that we do not decrease our sample size due to data availability. ${ }^{11}$ The results show that the magnitude of the conditional alignment effect $\theta$ even increases when controlling for donor and recipient-specific factors.

\footnotetext{
${ }^{11} \mathrm{~A}$ downside of this approach is that we cannot draw conclusions regarding the effect of leader change in instances where voting alignment is constant, since the fixed effects absorb this variable.
} 
TABLE 1

Dyadic Leader Changes

\begin{tabular}{lcccc}
\hline \hline & \multicolumn{4}{c}{ Dependent variable: ln ODA commitments } \\
& $(1)$ & $(2)$ & $(3)$ & $(4)$ \\
\hline Dyadic Leader change & -0.027 & & -0.020 & \\
& $(0.024)$ & & $(0.024)$ & -0.012 \\
Alignment change & & $0.501^{* *}$ & -0.015 & $(0.350)$ \\
& & $(0.209)$ & $(0.214)$ & $1.288^{* * *}$ \\
Leader change * realignment & & & $1.393^{* * *}$ & $(0.382)$ \\
& & & $(0.317)$ & $0.887^{*}$ \\
Last year alignment & $0.577^{* * *}$ & $1.006^{* * *}$ & $0.712^{* *}$ & $(0.528)$ \\
& $(0.218)$ & $(0.329)$ & $(0.324)$ & $0.838^{*}$ \\
Past mean alignment & $1.099^{* * *}$ & $0.813^{* * *}$ & $1.211^{* * *}$ & $(0.446)$ \\
& $(0.267)$ & $(0.271)$ & $(0.292)$ & \\
\hline Log GDP recipient & -0.136 & -0.135 & -0.131 & \\
& $(0.132)$ & $(0.133)$ & $(0.132)$ & \\
Log GDP donor & $2.302^{* * *}$ & $2.286^{* * *}$ & $2.283^{* * *}$ & \\
& $(0.649)$ & $(0.649)$ & $(0.647)$ & \\
Log population recipient & $0.804^{* *}$ & $0.806^{* *}$ & $0.810^{* *}$ & \\
& $(0.340)$ & $(0.340)$ & $(0.341)$ & \\
Log population donor & 0.147 & 0.278 & 0.459 & \\
& $(1.017)$ & $(1.028)$ & $(1.032)$ & \\
\hline Adjusted R-squared & 0.043 & 0.044 & 0.045 & 0.786 \\
Fixed Effects & $\mathrm{DR}, \mathrm{Y}$ & $\mathrm{DR}, \mathrm{Y}$ & $\mathrm{DR}, \mathrm{Y}$ & $\mathrm{DR}, \mathrm{RY}, \mathrm{DY}$ \\
\# of observations & 16928 & 16928 & 16928 & 18571 \\
\# of dyads & 668 & 668 & 668 & 681 \\
\hline \hline
\end{tabular}

Administration change variable in column 4 omitted due to fixed effects.

Fixed effects: donor-recipient (DR), year (Y), recipient-year (RY), donor-year (DY)

Robust standard errors in parentheses, clustered on donor-recipient dyad.

Significance levels: $* * * \mathrm{p}<0.01,{ }^{* *} \mathrm{p}<0.05,{ }^{*} \mathrm{p}<0.1$.

\section{A. Differences between Recipient and Donor Leader Changes}

In a next step, we investigate the conditional effect of leadership change and foreign policy realignment on the allocation of ODA commitments by differentiating between foreign policy changes that emanate either after a recipient or donor leader change (see Equation 2). ${ }^{12}$ The results are displayed in Table 2.

$$
\begin{aligned}
\operatorname{lnODA}_{i j t}= & \beta_{1} \cdot \text { recipient }_{i t}+\beta_{2} \cdot \text { donor }_{j t}+\delta \cdot \text { alignment }_{i j t} \\
& +\theta_{1} \cdot \text { recipient }_{i t} \cdot \text { alignment }_{i j t}+\theta_{2} \cdot \text { donor }_{j t} \cdot \text { alignment }_{i j t} \\
& +\phi \cdot \text { alignment }_{i j t-1}+\psi \cdot \text { meanalignment }_{i j d-1}+\mathbf{X}_{i j t}^{\prime} \boldsymbol{\eta}+\alpha_{i j}+\gamma_{t}+\epsilon_{i j t}
\end{aligned}
$$

\footnotetext{
${ }^{12}$ Note that $\beta$ and $\theta$ have been changed to $\beta_{1}$ and $\beta_{2}$ as well as $\theta_{1}$ and $\theta_{2}$. Although theoretically possible, we do not include mutual leader changes as a separate category because they are empirically too infrequent.
} 
Column 1 illustrates that the specific type of leader change matters for aid allocation. While changes in donor countries are statistically insignificant, leadership turnover in recipient countries leads to less ODA on average. Taken at face value, this would imply that donors are cautious towards heads of executive that take over power in recipient countries. However, the results in column 3 qualify this effect. The interactions between voting alignment change and both recipient and donor leader change are positive and statistically significant. Furthermore, the sizable interaction effect offsets the negative effect of recipient leader change with no voting alignment change. Hence, convergence gets rewarded while divergence leads to a reduction in ODA commitments, regardless whether voting re-alignment is a reaction of recipient countries to a new leader in a donor country or a re-alignment of foreign policy after domestic leader change. ${ }^{13}$

Furthermore, the effects remain stable when we include donor-recipient-pair, donoryear and recipient-year fixed effects (column 4). ${ }^{14}$ The results are robust to a even more conservative gravity model including the similarity indexes (Helpman, 1987) of GDP and population size. ${ }^{15}$ Taken together, these results strongly support our hypotheses.

To test if aid changes are indeed a political reaction, we test for other potential channels, such as trade, that vary between donor-recipient pairs over time. The bulk of bilateral trade between the G7 and other countries is driven by private firms that should care more about country specific issues like property rights (absorbed by the fixed effects) and less about political alignment. Hence, we would expect no effect on bilateral trade resulting from our proposed mechanism, nor should trade impair our mechanism with

\footnotetext{
${ }^{13}$ To properly test for autocorrelation, we reran all the models in Table 2 including lagged ODA commitments (results not reported). The lagged commitments are statistically significant, and have a point estimate up to 0.4 in the HDFE specification. A test for first order autocorrelation (Wooldridge, 2010; Drukker, 2003) cannot reject the null of no autocorrelation. Furthermore, a Fisher-test for a unit root in panel data using the Dickey-Fuller approach (Choi, 2001), utilizing up to 3 lags, neglects the presence of a unit root. We also included donor and recipient change and their respective interactions in separate regressions (results not reported). This leads to an increase in the magnitude and statistical significance of the single effects. Hence, our results are not driven by the simultaneous inclusion of both types of changes.

${ }^{14}$ The results are also robust to different forms of clustering (Cameron et al., 2011), such as clustering on donor and recipient or donor-recipient-pair and year.

${ }^{15}$ The similarity indexes are defined as follows: SimilarityIndex $(G D P)_{i j t}=1-\left(\frac{G D P_{i}}{G D P_{i} * G D P_{j}}\right)^{2}-$ $\left(\frac{G D P_{j}}{G D P_{i} * G D P_{j}}\right)^{2}$ and SimilarityIndex (Population $)_{i j t}=1-\left(\frac{P o p_{i}}{\text { Pop }_{i} * P_{p} p_{j}}\right)^{2}-\left(\frac{P o p_{j}}{P_{o p_{i} * P_{j}}}\right)^{2}$. Results of the specification are reported in column 2 of Table A-4
} 
TABLE 2

Dis-aggregate Leader Changes

\begin{tabular}{|c|c|c|c|c|}
\hline & \multicolumn{4}{|c|}{ Dependent variable: $\ln$ ODA commitments } \\
\hline & (1) & $(2)$ & (3) & (4) \\
\hline Recipient change & $\begin{array}{c}-0.104^{* * *} \\
(0.032)\end{array}$ & & $\begin{array}{c}-0.098^{* * *} \\
(0.032)\end{array}$ & \\
\hline Donor change & $\begin{array}{c}0.033 \\
(0.026)\end{array}$ & & $\begin{array}{l}0.045^{*} \\
(0.027)\end{array}$ & \\
\hline Alignment change & & $\begin{array}{c}0.501^{* *} \\
(0.209)\end{array}$ & $\begin{array}{c}0.002 \\
(0.219)\end{array}$ & $\begin{array}{c}0.034 \\
(0.350)\end{array}$ \\
\hline Recipient change ${ }^{*}$ realignment & & & $\begin{array}{c}1.370^{* * *} \\
(0.406)\end{array}$ & $\begin{array}{c}1.187^{* *} \\
(0.502)\end{array}$ \\
\hline Donor change $*$ realignment & & & $\begin{array}{c}1.031^{* * * *} \\
(0.334)\end{array}$ & $\begin{array}{l}0.877^{*} \\
(0.472)\end{array}$ \\
\hline Last year alignment & $\begin{array}{c}0.572^{* * *} \\
(0.218)\end{array}$ & $\begin{array}{c}1.006^{* * *} \\
(0.329)\end{array}$ & $\begin{array}{c}0.735^{* *} \\
(0.326)\end{array}$ & $\begin{array}{l}0.937^{*} \\
(0.529)\end{array}$ \\
\hline Past mean alignment & $\begin{array}{c}1.082^{* * *} \\
(0.266)\end{array}$ & $\begin{array}{c}0.813^{* * *} \\
(0.271)\end{array}$ & $\begin{array}{c}1.127^{* * *} \\
(0.284)\end{array}$ & $\begin{array}{l}0.730^{*} \\
(0.434)\end{array}$ \\
\hline Log GDP recipient & $\begin{array}{l}-0.141 \\
(0.132)\end{array}$ & $\begin{array}{l}-0.135 \\
(0.133)\end{array}$ & $\begin{array}{c}-0.136 \\
(0.132)\end{array}$ & \\
\hline Log GDP donor & $\begin{array}{c}2.254^{* * *} \\
(0.648)\end{array}$ & $\begin{array}{c}2.286^{* * *} \\
(0.649)\end{array}$ & $\begin{array}{c}2.246^{* * *} \\
(0.646)\end{array}$ & \\
\hline Log population recipient & $\begin{array}{c}0.794^{* *} \\
(0.340)\end{array}$ & $\begin{array}{c}0.806^{* *} \\
(0.340)\end{array}$ & $\begin{array}{c}0.792^{* *} \\
(0.341)\end{array}$ & \\
\hline Log population donor & $\begin{array}{c}0.170 \\
(1.017) \\
\end{array}$ & $\begin{array}{c}0.278 \\
(1.028) \\
\end{array}$ & $\begin{array}{c}0.412 \\
(1.030) \\
\end{array}$ & \\
\hline$\overline{\text { Adjusted R-squared }}$ & 0.044 & 0.044 & 0.046 & 0.786 \\
\hline Fixed Effects & $\mathrm{DR}, \mathrm{Y}$ & $\mathrm{DR}, \mathrm{Y}$ & $\mathrm{DR}, \mathrm{Y}$ & DR,RY,DY \\
\hline \# of observations & 16928 & 16928 & 16928 & 18571 \\
\hline \# of dyads & 668 & 668 & 668 & 681 \\
\hline
\end{tabular}

Leader change variables in column 4 are omitted due to fixed effects.

Fixed effects: donor-recipient (DR), year (Y), recipient-year (RY), donor-year (DY)

Robust standard errors in parentheses, clustered on donor-recipient dyad.

Significance levels: ${ }^{* * *} \mathrm{p}<0.01,{ }^{* *} \mathrm{p}<0.05,{ }^{*} \mathrm{p}<0.1$.

regard to aid. This is exactly what we find. The inclusion of bilateral donor and recipient imports do not change our conditional alignment effect Table A-4. Falsification tests, in which we replace ODA commitments with both donor and recipient imports, yield also no results (column 4 and 5 of Table A-4). ${ }^{16}$

How consequential are these effects for recipient's revenue streams? To answer this question, we estimate the predicted change of ODA commitments in percentage points

\footnotetext{
${ }^{16}$ Testing for other channels, such as FDI or remittances, is more difficult, as data availability is not sufficiently high for our sample. Remittances, for example, are only available on the recipient country level and not bilaterally before 2005 .
} 
Figure 1

Marginal Effect of Leader Change, Conditional on Alignment Change

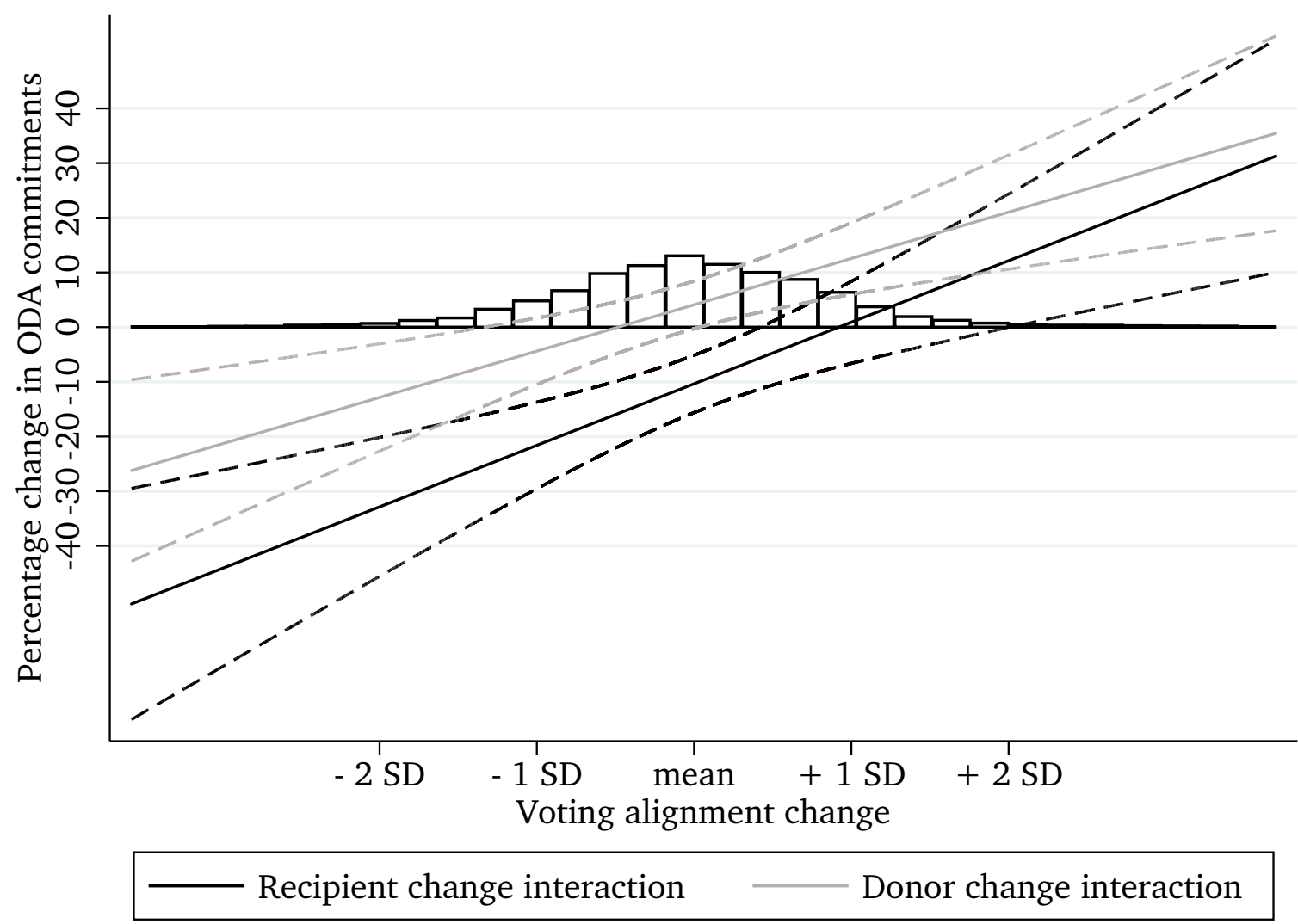

with respect to the change in voting alignment and the type of leadership turnover (based on model 3 in Table 2). The results are plotted in Figure 1. At the mean alignment change, representing marginal dis-alignment (see Table A-2), new recipient leaders receive $9.7 \%$ less ODA commitments in their first year. In the opposite case of donor leader change, they receive $3.8 \%$ higher ODA commitments.

If a newly inaugurated recipient leader, however, chooses to dis-align by one standard deviation - which is approximately a 8 percentage point decrease in voting alignment from one year to another - ODA commitments to this country shrink by $19.6 \%$. Hence, decreasing political proximity with donor countries in the UNGA increases the negative effect of domestic leader change by about 10 percentage points for aid recipients. In case of donor leader change, dis-alignment seems to have no substantial effect. Conversely, foreign policy convergence gets rewarded with additional aid. A move towards the donor by one standard deviation results in $9.1 \%$ more ODA commitments. In substantial terms, 
these numbers show that signaling political accord or animosity matters a great deal in times of high uncertainty in bilateral relations, especially with regard to the economic implications of politically granted development aid. ${ }^{17}$ Consider for example that the median aid recipient in our sample receives around $\$ 100 \mathrm{~m}$ in development aid from the G7 annually. According to our results, if a new recipient country leader were to alter their foreign policy proximity to international aid providers by one standard deviation, the country would face a cut of $19.6 \%$, i.e. almost $\$ 20 \mathrm{~m}$.

Summing up, political re-alignment after leader change is highly consequential for recipient countries. While new recipient leaders can mainly forgo cutbacks by aligning themselves with donors, existing recipient country leaders have an opportunity to fill the public purse when a new donor leader enters office.

\section{B. Timing}

How lasting is the conditional alignment effect? If our argument were correct, future leader changes and their initial foreign policy shifts should not predict aid today. Nor should the initial foreign policy position taken by a new leader predict all future aid commitments. Instead, we would expect that the initial behavior becomes less relevant as soon as the donor-recipient pair gets a good estimate about how their relations actually are. To explore the time structure, we re-estimate the high dimensional fixed effect estimation (Table 2, column 4) using several leads and lags of our dependent variable. ${ }^{18}$ Figure 2 plots the point estimates and their $90 \%$ confidence intervals of the recipient and donor leader interactions with UNGA voting changes.

Both interaction effects are not statistically different from zero before the year of the actual leader change $t$. This makes us confident, that it is indeed the initial foreign policy change of a new leader that has an effect on aid commitments rather than a general change in bilateral relations that is only accompanied by leader change. Likewise

\footnotetext{
${ }^{17}$ Note further that the size of the alignment change effect is much more pronounced in case of recipient leader change than for donor leader change. This is due to the fact that all donor countries react to recipient leader change at once, while only the affected donor reacts after donor leader change.

${ }^{18}$ Because the median duration of the leader pair dyad is five years, we use two years prior to and after each leader change, in addition to the contemporaneous specification.
} 
Figure 2

Timing of the Conditional Alignment Effect
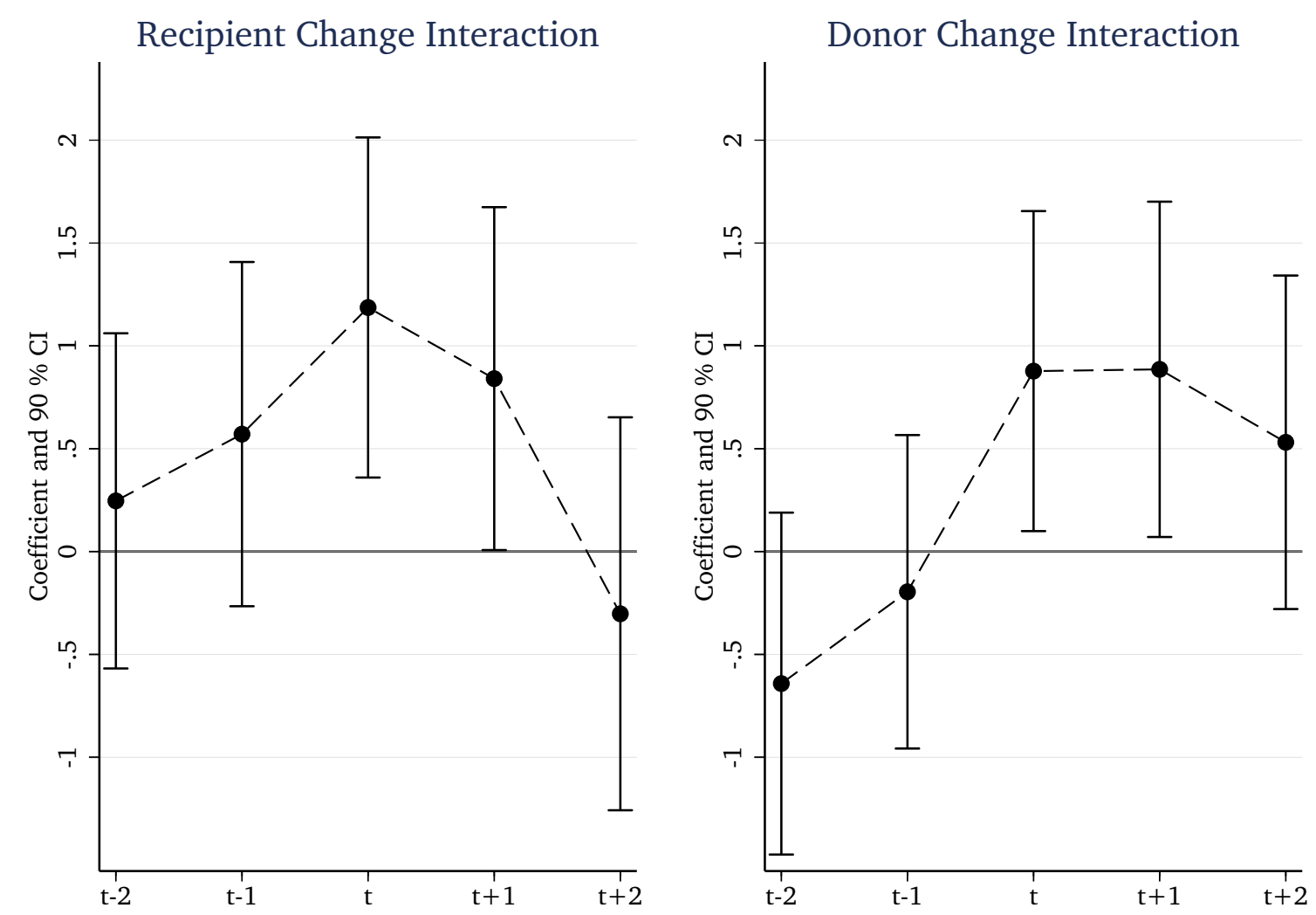

Notes: The underlying regression specifications are reported in Table A-5 in the appendix. Standard errors are clustered at the donor-recipient dyad. The interaction between recipient leader change and alignment change at time $\mathrm{t}$ is statistically significant at the $5 \%$ level, the interaction between donor leader change and alignment change is significant at the $10 \%$ level.

both interactions lose statistical significance two years after the respective leader change. Hence, the substantial effects are, as expected, rather short lived.

Nonetheless, it might still be the case that our results are driven by spurious correlation that covaries with the leader change interactions within the dyads over time. In order to test for this, we follow Hsiang and Jina (2014) and conduct a randomization test over all dimensions of our panel. More specifically we conduct three randomizations of our respective interaction terms on the basis of model 4 in Table 2: First, we randomize leader changes over the whole sample. Hence, a leader change in Kenya in 2000 can be assigned to Indonesia in 1990. Second, we randomize between dyads, thus keeping the time structure of the leader changes constant, which means that the entire leader change pattern of Kenya is, for example, assigned to Indonesia. This tests for spurious correlation 
FiguRe 3

Randomization of Leader Change

Recipient Change Randomization
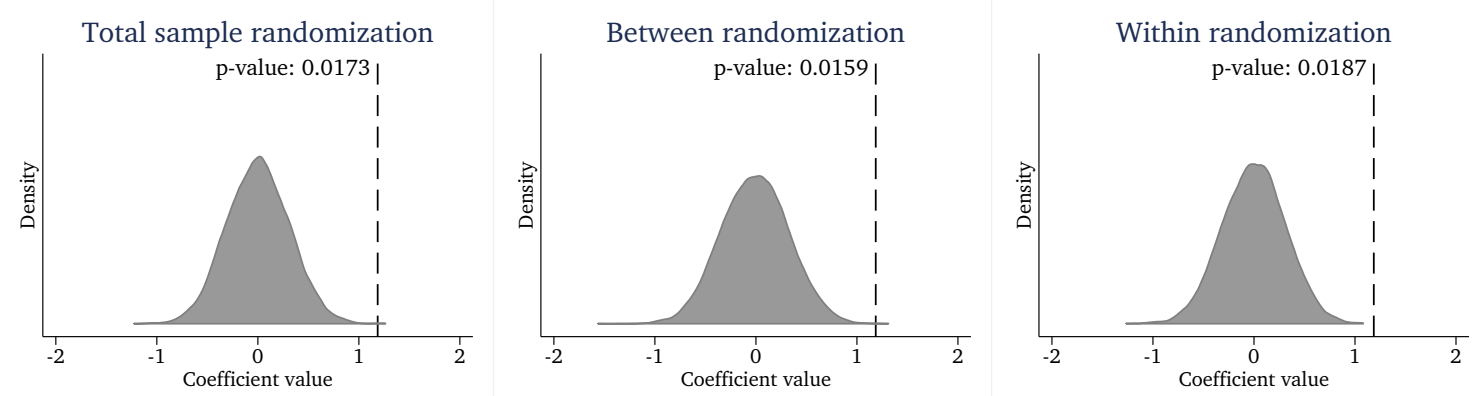

Donor Change Randomization
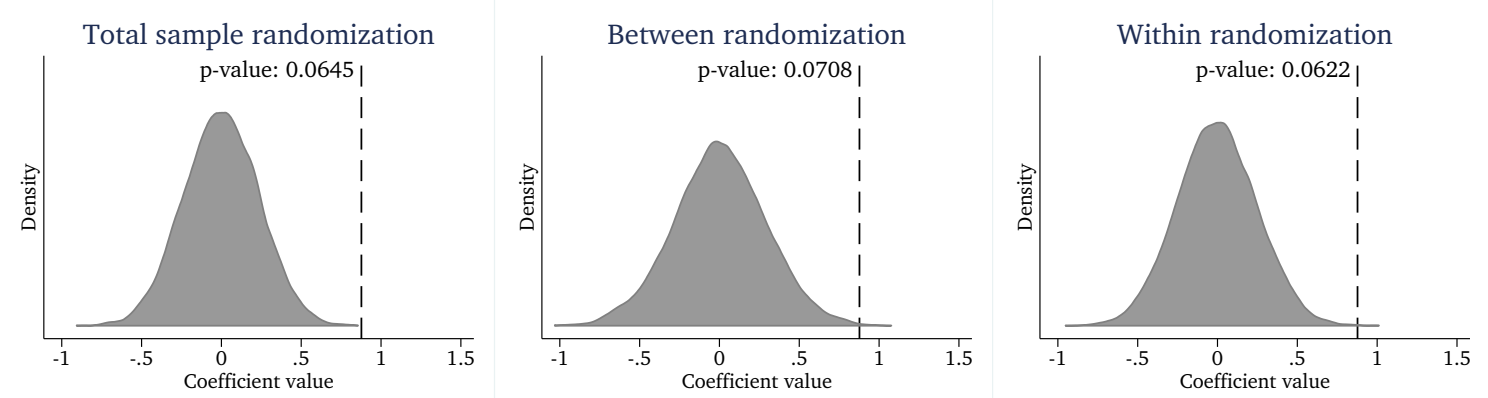

Notes: Distribution of point estimates for the interaction between recipient change and alignment change, based on Table 2, column 4. Each distribution corresponds to the different dependentindependent variable pairs, for the three different randomization procedures. Each distribution is constructed by repeating the randomization and estimation procedure 10000 times. The point coefficient of the actual estimation is depicted as a vertical line.

arising from country or regional time trends, for example because the US closely monitors countries voting behavior in the Middle East at the time of the wars in Iraq. Third, we randomize leader changes within each dyad, but not across dyads. Thus, leader changes in Kenya are shuffled around within Kenya. This randomization allows us to test if any unobserved dyadic-specific circumstances that vary over time drive the results, for instance conflicts over trade between countries that covary with the leader changes within dyads or covert operations between donors and recipients, such as CIA interventions (Berger et al., 2013). We expect that all randomization procedures do not produce point estimates equal or above the point coefficients obtained from the real data structure.

Figure 3 presents the kernel density function of the resulting point coefficients of the recipient leader and donor leader change interactions for each of the three randomization 
exercises, resulting from 10000 randomization iterations. The recipient change results are reported in the upper panel, while the donor change interaction results are plotted in the lower panel. The dotted line represents the obtained point coefficient from the actual data based on column 4 in Table 2. The p-values are obtained from a Fisher's exact test. In all cases, the estimated interaction terms using the real data exceed the coefficients obtained from the hypothetical scenarios. The p-values range between 0.0159 to 0.0187 for the recipient change interactions and 0.0622 and 0.0708 for the donor interactions, which is very close to the original p-values. It is thus highly unlikely that our results are driven by any spurious correlation, either within or between panels. Hence, it is indeed the leader change interaction that drives changes in ODA commitments between donors and recipients.

\section{Scope}

To evaluate the scope of of the conditional alignment effect, we investigate how different institutional settings and types of leader transitions affect the alignment mechanism. We start by differentiating between legal and illegal leadership change. If donors care about the rule of law, they should oppose illegal power grabs by cutting financial support. We code illegal changes as irregular entries into office, for example via coups (Goemans et al., 2009). We do so only for recipient countries, as there are no illegal changes in the G7 countries in our sample. The results in Table 3 column 1 show a positive and statistically significant alignment change effect in both cases. Furthermore, a t-test fails to reject that the coefficients are equal.

In column 2, we interact our model with a proxy for political struggle, operationalized as years during which a country has had more than two heads of executive. In such cases, the alignment change interaction becomes insignificant. This might point to the fact that donors are incapable of gaining enough information during very short executive tenures in recipient states. Thus, they are unable to figure out who they are dealing with and thus revert to their 'standard' aid allocation.

In column 3, we test whether domestic-support-group change in addition to leader 
TABLE 3

Scope of the Conditional Alignment Effect

\begin{tabular}{|c|c|c|c|c|c|}
\hline & \multicolumn{5}{|c|}{ Dependent variable: $\ln O D A$ commitments } \\
\hline & (1) & (2) & $\begin{array}{l}\text { Mattes } \\
\text { et al. } 2015 \\
\text { (3) }\end{array}$ & $\begin{array}{c}\text { Dreher and } \\
\text { Jensen } 2013 \\
\text { (4) }\end{array}$ & $\begin{array}{c}\text { Carter and } \\
\text { Stone } 2015 \\
\text { (5) }\end{array}$ \\
\hline Last year alignment & $\begin{array}{c}0.745^{* *} \\
(0.328)\end{array}$ & $\begin{array}{c}0.392 \\
(0.295)\end{array}$ & $\begin{array}{c}0.405 \\
(0.292)\end{array}$ & $\begin{array}{c}0.677^{* *} \\
(0.315)\end{array}$ & $\begin{array}{c}0.659^{* *} \\
(0.314)\end{array}$ \\
\hline Past mean alignment & $\begin{array}{c}1.104^{* * *} \\
(0.284)\end{array}$ & $\begin{array}{c}0.629^{* *} \\
(0.301)\end{array}$ & $\begin{array}{l}0.568^{*} \\
(0.299)\end{array}$ & $\begin{array}{c}0.923^{* * *} \\
(0.289)\end{array}$ & $\begin{array}{c}0.889^{* * * *} \\
(0.285)\end{array}$ \\
\hline & $\begin{array}{c}\text { Legal } \\
\text { change }\end{array}$ & $\begin{array}{l}\text { Without } \\
\text { struggle }\end{array}$ & $\begin{array}{l}\text { Support } \\
\text { constant }\end{array}$ & $\begin{array}{c}\text { During } \\
\text { Cold War }\end{array}$ & Autocracy \\
\hline Recipient change & $\begin{array}{c}-0.092^{* * *} \\
(0.034)\end{array}$ & $\begin{array}{c}-0.091^{* * *} \\
(0.031)\end{array}$ & $\begin{array}{c}-0.129^{* *} \\
(0.057)\end{array}$ & $\begin{array}{c}-0.129^{* *} \\
(0.062)\end{array}$ & $\begin{array}{c}-0.104^{* *} \\
(0.044)\end{array}$ \\
\hline Donor change & $\begin{array}{l}0.045^{*} \\
(0.027)\end{array}$ & $\begin{array}{c}0.040 \\
(0.026)\end{array}$ & $\begin{array}{c}0.090^{* *} \\
(0.045)\end{array}$ & $\begin{array}{c}0.027 \\
(0.054)\end{array}$ & $\begin{array}{c}0.040 \\
(0.031)\end{array}$ \\
\hline Alignment change & $\begin{array}{c}0.039 \\
(0.220)\end{array}$ & $\begin{array}{l}-0.139 \\
(0.206)\end{array}$ & $\begin{array}{l}-0.100 \\
(0.199)\end{array}$ & $\begin{array}{l}-0.288 \\
(0.356)\end{array}$ & $\begin{array}{l}-0.033 \\
(0.220)\end{array}$ \\
\hline Recipient change $*$ realignment & $\begin{array}{l}1.030^{* *} \\
(0.445)\end{array}$ & $\begin{array}{c}1.277^{* * * *} \\
(0.393)\end{array}$ & $\begin{array}{l}1.193^{*} \\
(0.675)\end{array}$ & $\begin{array}{l}1.328^{*} \\
(0.712)\end{array}$ & $\begin{array}{l}0.896^{*} \\
(0.535)\end{array}$ \\
\hline Donor change $*$ realignment & $\begin{array}{c}1.023^{* * *} \\
(0.333)\end{array}$ & $\begin{array}{c}0.629^{* *} \\
(0.315)\end{array}$ & $\begin{array}{c}0.449 \\
(0.718)\end{array}$ & $\begin{array}{c}0.761 \\
(0.551)\end{array}$ & $\begin{array}{c}1.148^{* * *} \\
(0.365)\end{array}$ \\
\hline & $\begin{array}{l}\text { Illegal } \\
\text { change }\end{array}$ & $\begin{array}{c}\text { Struggle } \\
\text { year }\end{array}$ & $\begin{array}{l}\text { Support } \\
\text { change }\end{array}$ & $\begin{array}{c}\text { After } \\
\text { Cold War }\end{array}$ & Democracy \\
\hline Recipient change & $\begin{array}{c}-0.172^{* *} \\
(0.073)\end{array}$ & $\begin{array}{c}-0.159 \\
(0.177)\end{array}$ & $\begin{array}{l}-0.067^{*} \\
(0.036)\end{array}$ & $\begin{array}{c}-0.077^{* *} \\
(0.036)\end{array}$ & $\begin{array}{c}-0.095^{* * *} \\
(0.036)\end{array}$ \\
\hline Donor change & & & $\begin{array}{c}0.042 \\
(0.037)\end{array}$ & $\begin{array}{l}0.054^{*} \\
(0.032)\end{array}$ & $\begin{array}{c}0.056 \\
(0.045)\end{array}$ \\
\hline Alignment change & & & & $\begin{array}{c}0.374 \\
(0.363)\end{array}$ & $\begin{array}{c}0.184 \\
(0.368)\end{array}$ \\
\hline Recipient change $*$ realignment & $\begin{array}{l}1.196^{*} \\
(0.724)\end{array}$ & $\begin{array}{l}-1.772 \\
(1.276)\end{array}$ & $\begin{array}{c}1.595^{* * *} \\
(0.466)\end{array}$ & $\begin{array}{c}1.082^{* *} \\
(0.474)\end{array}$ & $\begin{array}{c}1.702^{* * *} \\
(0.561)\end{array}$ \\
\hline Donor change $*$ realignment & & & $\begin{array}{l}0.701^{*} \\
(0.368)\end{array}$ & $\begin{array}{c}1.241^{* * *} \\
(0.390)\end{array}$ & $\begin{array}{c}0.305 \\
(0.579)\end{array}$ \\
\hline Adjusted R-squared & 0.045 & 0.031 & 0.034 & 0.054 & 0.054 \\
\hline Fixed Effects & $\mathrm{DR}, \mathrm{Y}$ & $\mathrm{DR}, \mathrm{Y}$ & $\mathrm{DR}, \mathrm{Y}$ & $\mathrm{DR}, \mathrm{Y}$ & $\mathrm{DR}, \mathrm{Y}$ \\
\hline \# of observations & 16928 & 18571 & 18571 & 17477 & 17607 \\
\hline \# of dyads & 668 & 681 & 681 & 667 & 672 \\
\hline
\end{tabular}

Column 1 includes GDP and population controls.

Column 2 includes no additional controls.

See Table A-6 for information on control variables in columns 3 to 5 .

Fixed effects: donor-recipient (DR), year (Y), recipient-year (RY), donor-year (DY)

Robust standard errors in parentheses, clustered on donor-recipient dyad.

Significance levels: $* * * \mathrm{p}<0.01,{ }^{* *} \mathrm{p}<0.05,{ }^{*} \mathrm{p}<0.1$.

change amplifies the effects from changes in voting alignment. Domestic-support-group changes follow the same logic as changes in the political orientation of the government (Potrafke, 2017). If the domestic support group changes, it is likely that different societal 
interest are primarily considered by the government. ${ }^{19}$ Mattes et al. (2015) highlight that changes in the domestic support groups are the main driver of significant foreign policy re-alignment. We adapt their specification by including their core set of control variables in our dyadic setting (see Table A-6). ${ }^{20}$ We find evidence in favor of our argument regardless of a simultaneous change in the support group of the leader - the interaction term is positive and statistically significant in both cases. At first glance the magnitude of the point estimate is higher in the case of domestic support group change. The t-test, however, indicates no difference between the coefficients. Thus, alterations in the conditions surrounding leader change do not seem to reduce the importance of first impressions.

We further differentiate between different eras as well as institutional settings (see Table A-3). In column 4, we adopt the Dreher and Jensen (2013) specification and differentiate between the Cold War and post-Cold War period, ${ }^{21}$ but use all votes in the UNGA instead of focusing on key votes alone. In column 5, we subdivide the sample into democracies and autocracies. Carter and Stone (2015) have shown that donors actually prefer to provide political side payments to fellow democracies, since their own constituencies are more skeptical of financial support to autocracies compared to democracies. The interaction terms between leader change and changes in political proximity show the expected results, but reveal interesting variation in terms of effect size and statistical significance. For example, the donor change interaction is only significant in the post-Cold War period and for autocratic recipient countries. The recipient interactions are however not statistically different from one another between time periods. Interestingly, the point estimate of the interaction effect is about twice as large for democratically elected leaders. The presence of the interaction effects for both democratic and autocratic countries increases our confidence that we have not simply picked up lagged election effects (Faye and Niehaus, 2012), since many of the autocratic countries in our sample do not hold competitive elec-

\footnotetext{
${ }^{19}$ While domestic support group changes tell us little about the political orientation of the government, they tell us if switches in aggregated preferences occurred, thus highlighting our uncertainty argument. Another upside of domestic support group changes in comparison to ideology changes is that the latter are hard to grasp for a lot of recipient countries.

${ }^{20}$ Due to space restrictions, we do not report the coefficients of the additional control variables. They are, however, in line with the findings of previous research.

${ }^{21}$ Voeten (2000) has shown that voting blocks are less stable after the end of the Cold War.
} 
tions. Again, there is no difference between the interactions of recipient leader change and alignment changes between autocracies and democracies. We attribute this in part to an imprecise estimate in the autocratic setting, driven by relatively few leader changes.

\section{Robustness Tests}

In this section we further probe the robustness of our findings. We check for problems of endogeneity and conclude that our results do not seem to be driven by reverse causality. We rule out selection effects on the dependent variable and use alternative measures of foreign policy alignment to demonstrate that our results are not subject to specific coding decisions. Finally, we show that the results are not driven by the allocation decisions of single donors.

\section{A. Reverse Causality}

Studies point to the fact that donors engage in vote buying (Dreher and Sturm, 2012; Carter and Stone, 2015), intervene in or influence elections in recipient countries (Faye and Niehaus, 2012), or use other means to oust unfavorable political leaders and regimes in order to achieve commercial objectives. ${ }^{22}$ Hence, political convergence (or divergence) between a recipient and donor may depend on commitments (or threats) made by donors prior to leader turnover in a recipient state. The same problem applies to leader turnover in donor countries. A new US president may alter aid commitments made to recipients directly after inauguration, thus driving recipients to change their alignment strategies.

To tackle this issue we utilize an instrumental variables framework. Ideally we would instrument donor and recipient leader change as well as foreign policy alignment. Unfortunately, we lack instruments for foreign policy alignment and can only instrument leader changes. Bun and Harrison (2014), however, indicate that the interaction term between an exogenous and an endogenous variable is itself exogenous as long as there is no contemporaneous reverse causality or anticipation effects.

\footnotetext{
${ }^{22}$ Berger et al. (2013) provide a comprehensive list of United States' CIA interventions into the domestic politics of developing countries during the Cold War.
} 
We follow Annen and Strickland (2017) and instrument donor leader changes with regular (executive and legislative) elections in donor countries. In addition, we include presidential term limits. ${ }^{23}$ We instrument recipient leader changes using natural deaths of executive leaders (Jones and Olken, 2005) as well as legislative and executive elections. ${ }^{24}$ The election data is taken from the National Elections Across Democracy and Autocracy (NELDA) database (Hyde et al., 2012). ${ }^{25}$ Note that we only include 'regular' elections, which are elections that occur at their scheduled date and not elections that have been postponed or held after regular elections have been tempered with. ${ }^{26}$

Our identifying assumption is that none of these variables affects ODA commitments besides their effect via actual leader change and the foreign policy alignment that occurs in tandem. While this assumption is rather straight-forward in case of term limits, natural deaths, and election dates in donor countries, it could be more problematic for recipient countries. For one, Faye and Niehaus (2012) show that donors increase aid commitments to friendly regimes during election years, while they reduce aid to hostile regimes. Yet, their mechanism is conditional on alignment, for which we control. Hence, the conditional independence assumption should hold as long as we control for lagged alignment.

Table 4 present the first stage results of our instrumental variables regressions. Note that our instruments perform better in predicting donor leader change than recipient leader change, as shown by the adjusted R-squared in Table 4. This is not surprising, since elections in many recipient countries are not as competitive as in donor countries. Hence, they have less power in predicting leader change. Moreover, we cannot include donor and recipient year fixed effects since our instruments vary only by donor and recipient year.

Table 5 presents the second stage results of our instrumental variables approach. We report both 2SLS and control function results. Using regular 2SLS in column 1,

\footnotetext{
${ }^{23}$ Term limits are only available for the US.

${ }^{24}$ No donor leader has died a natural death in office within our sample. Hence, we cannot use natural deaths as an instrument for donor leader change.

${ }^{25}$ For detailed information on the data see Hyde et al. (2012) and the original application in Annen and Strickland (2017).

${ }^{26}$ Since we always code the leader with the most days in office during a year as the current leader, we lead elections occurring after July 1 by one year. By definition a new leader would not be coded for the current year and the change would occur in the following year.
} 
TABLE 4

Instrumental Variables: First Stages

\begin{tabular}{|c|c|c|c|c|}
\hline & \multicolumn{4}{|c|}{ Dependent variables: Leader Changes } \\
\hline & (1) & $(2)$ & $(3)$ & $(4)$ \\
\hline & Recipient & Donor & Recipient & Donor \\
\hline & change & Change & change & change \\
\hline & & & *alignment & *alignment \\
\hline \multirow[t]{2}{*}{ Alignment change } & $-0.105^{* *}$ & $0.281^{* * *}$ & $0.125^{* * *}$ & $0.192^{* * *}$ \\
\hline & $(0.052)$ & $(0.050)$ & $(0.011)$ & $(0.015)$ \\
\hline \multirow[t]{2}{*}{ Last year alignment } & $-0.284^{* * *}$ & $0.145^{* *}$ & $0.067^{* * *}$ & $0.128 * * *$ \\
\hline & $(0.068)$ & $(0.058)$ & $(0.009)$ & $(0.013)$ \\
\hline \multirow[t]{2}{*}{ Past mean alignment } & $0.261^{* * *}$ & $0.257^{* * *}$ & $-0.088^{* * *}$ & $-0.148^{* * *}$ \\
\hline & $(0.068)$ & $(0.058)$ & $(0.009)$ & $(0.011)$ \\
\hline \multicolumn{5}{|c|}{ Instruments } \\
\hline \multirow[t]{2}{*}{ Natural death of recipient leader } & $0.933^{* * *}$ & 0.020 & 0.001 & -0.002 \\
\hline & $(0.009)$ & $(0.030)$ & $(0.001)$ & $(0.004)$ \\
\hline \multirow[t]{2}{*}{ Executive election (Recipient) } & $0.204^{* * *}$ & $0.036^{* *}$ & 0.002 & 0.001 \\
\hline & $(0.027)$ & $(0.015)$ & $(0.002)$ & $(0.002)$ \\
\hline \multirow[t]{2}{*}{ Legislative election (Recipient) } & 0.018 & $0.022^{* *}$ & $-0.001^{*}$ & -0.001 \\
\hline & $(0.015)$ & $(0.011)$ & $(0.001)$ & $(0.001)$ \\
\hline \multirow[t]{2}{*}{ Leader term limit (Donor) } & -0.019 & $1.194^{* * *}$ & $0.004^{*}$ & $-0.009^{* * *}$ \\
\hline & $(0.026)$ & $(0.009)$ & $(0.002)$ & $(0.001)$ \\
\hline \multirow[t]{2}{*}{ Executive election (Donor) } & -0.006 & $0.048^{* *}$ & 0.001 & $0.008^{* * *}$ \\
\hline & $(0.012)$ & $(0.020)$ & $(0.001)$ & $(0.001)$ \\
\hline \multirow[t]{2}{*}{ Legislative election (Donor) } & 0.009 & $0.172^{* * *}$ & -0.000 & $-0.007^{* * *}$ \\
\hline & $(0.007)$ & $(0.007)$ & $(0.000)$ & $(0.001)$ \\
\hline \multicolumn{5}{|c|}{ Instruments ${ }^{*}$ alignment change } \\
\hline \multirow[t]{2}{*}{ Natural death of recipient leader } & $0.180^{* *}$ & $-0.518^{*}$ & $0.869^{* * *}$ & 0.030 \\
\hline & $(0.080)$ & $(0.279)$ & $(0.014)$ & $(0.063)$ \\
\hline \multirow[t]{2}{*}{ Executive election (Recipient) } & $0.504^{* *}$ & 0.131 & $0.084^{* *}$ & 0.114 \\
\hline & $(0.238)$ & $(0.231)$ & $(0.042)$ & $(0.081)$ \\
\hline \multirow[t]{2}{*}{ Legislative election (Recipient) } & $-0.319 * * *$ & -0.120 & 0.005 & -0.021 \\
\hline & $(0.121)$ & $(0.144)$ & $(0.021)$ & $(0.031)$ \\
\hline \multirow[t]{2}{*}{ Leader term limit (Donor) } & -0.087 & $0.633^{* * *}$ & 0.019 & $0.764^{* * *}$ \\
\hline & $(0.239)$ & $(0.105)$ & $(0.040)$ & $(0.019)$ \\
\hline \multirow[t]{2}{*}{ Executive election (Donor) } & -0.055 & $2.194^{* * *}$ & -0.007 & 0.000 \\
\hline & $(0.142)$ & $(0.170)$ & $(0.025)$ & $(0.050)$ \\
\hline \multirow[t]{2}{*}{ Legislative election (Donor) } & 0.034 & $-1.613^{* * *}$ & 0.023 & $0.213^{* * *}$ \\
\hline & $(0.074)$ & $(0.100)$ & $(0.015)$ & $(0.027)$ \\
\hline$\overline{\text { Adjusted R-squared }}$ & 0.093 & 0.320 & 0.228 & 0.427 \\
\hline Fixed Effects & $\mathrm{DR}, \mathrm{Y}$ & $\mathrm{DR}, \mathrm{Y}$ & $\mathrm{DR}, \mathrm{Y}$ & $\mathrm{DR}, \mathrm{Y}$ \\
\hline \# of observations & 15581 & 15581 & 15581 & 15581 \\
\hline \# of dyads & 668 & 668 & 668 & 668 \\
\hline
\end{tabular}

Each column represents one of the first stages of model 1 Table 4.

All specifications include GDP and population controls.

Fixed effects: donor-recipient (DR), year (Y), recipient-year (RY), donor-year (DY)

Robust standard errors in parentheses, clustered on donor-recipient dyad.

Significance levels: ${ }^{* * *} \mathrm{p}<0.01,{ }^{* *} \mathrm{p}<0.05,{ }^{*} \mathrm{p}<0.1$. 
we find that the donor-change interaction is positive and statistically significant. It even increases in size compared to the original effect (see column 3 in Table 2). The interaction between recipient country leader change and foreign policy alignment is not statistically significant. Note, however, that the recipient leader change interaction is estimated very imprecisely, and the interacted instruments do not really add exogenous variation (see the first stage results). ${ }^{27}$

TABLE 5

Instrumental Variables: Second Stages

\begin{tabular}{|c|c|c|c|}
\hline & \multicolumn{3}{|c|}{ Dependent variable: $\ln O D A$ commitments } \\
\hline & (1) & $(2)$ & $(3)$ \\
\hline & $2 S L S$ & Control Function & Control Function \\
\hline \multirow[t]{2}{*}{ Recipient change } & $-0.224^{*}$ & $-0.232^{*}$ & $-0.225^{*}$ \\
\hline & $(0.116)$ & $(0.120)$ & $(0.119)$ \\
\hline \multirow[t]{2}{*}{ Donor change } & 0.032 & 0.013 & 0.027 \\
\hline & $(0.054)$ & $(0.053)$ & $(0.054)$ \\
\hline \multirow[t]{2}{*}{ Alignment change } & -0.064 & -0.101 & -0.282 \\
\hline & $(0.398)$ & $(0.244)$ & $(0.241)$ \\
\hline \multirow[t]{2}{*}{ Recipient change ${ }^{*}$ realignment } & -0.291 & $1.423^{* * *}$ & $1.402^{* * *}$ \\
\hline & $(1.787)$ & $(0.423)$ & $(0.418)$ \\
\hline \multirow[t]{2}{*}{ Donor change $*$ realignment } & $1.840^{* *}$ & $1.065^{* * *}$ & $0.927^{* * *}$ \\
\hline & $(0.900)$ & $(0.344)$ & $(0.333)$ \\
\hline \multirow[t]{2}{*}{ Last year alignment } & 0.613 & $0.601^{*}$ & 0.234 \\
\hline & $(0.376)$ & $(0.344)$ & $(0.345)$ \\
\hline \multirow[t]{2}{*}{ Past mean alignment } & $1.226^{* * *}$ & $1.263^{* * *}$ & $0.889^{* *}$ \\
\hline & $(0.354)$ & $(0.311)$ & $(0.312)$ \\
\hline \multicolumn{4}{|c|}{ Control function Residuals } \\
\hline \multirow{2}{*}{\multicolumn{2}{|c|}{ Recipient change (residual) }} & 0.155 & 0.142 \\
\hline & & $(0.125)$ & $(0.124)$ \\
\hline \multirow[t]{2}{*}{ Donor change (residual) } & & 0.042 & 0.040 \\
\hline & & $(0.062)$ & $(0.064)$ \\
\hline Within R-squared & 0.047 & 0.050 & 0.423 \\
\hline Fixed Effects & $\mathrm{DR}, \mathrm{Y}$ & $\mathrm{DR}, \mathrm{Y}$ & $\mathrm{DR}, \mathrm{Y}$ \\
\hline F-stat IV & 237.8 & 237.8 & 209.1 \\
\hline Obs & 15576 & 15581 & 15581 \\
\hline Dyads & 663 & 668 & 668 \\
\hline
\end{tabular}

Columns 1 and 2 include GDP and population controls.

Fixed effects: donor-recipient (DR), year (Y), recipient-year (RY), donor-year (DY)

Robust standard errors in parentheses, clustered on donor-recipient dyad.

Significance levels: ${ }^{* * *} \mathrm{p}<0.01,{ }^{* *} \mathrm{p}<0.05,{ }^{*} \mathrm{p}<0.1$.

Since our instrument interactions do not add exogenous variation on the first stage, we focus on a control function approach, which increases efficiency, given mild assumptions

\footnotetext{
${ }^{27}$ Nonetheless, the Hansen J-test of over-identification is rejected with a test statistic of 12.964 .
} 
(Wooldridge, 2010, 2015). Control functions do not need the residuals of our interaction instruments in order to produce consistent estimators. Column 2 reports the control function estimates, where the standard errors are obtained from 999 bootstraps. $^{28}$ In this case both the donor and recipient interactions are positive, statistically significant, and comparable in size to the previous results. In addition, we follow a recent debate in econometrics and exclude our control variables form the control function (Angrist and Pischke, 2008), since neither GDP nor population should add to the conditional independence between our instruments and leader change (see Table 5, column 3). Again, the results support our argument. All in all, it is not surprising that the obtained LATE does not differ much from the original results since donors do not seem to care too much about the circumstances surrounding recipient leader changes.

Lastly, because the identification of our interaction variables rests on the absence of anticipation effects of the alignment change (Bun and Harrison, 2014), we reestimate our core models with alignment change as the dependent variable and use lagged ODA commitments as well as interactions of leader change with lagged ODA commitments as independent variables (see Table A-7). We obtain a small level-coefficient of lagged ODA commitments on the alignment change, no effect for the recipient interaction with lagged ODA, and a small effect of the interaction between donor change and lagged ODA, which is consistent with the findings of Annen and Strickland (2017). Note however that none of these interaction effects is statistically significant if we include donor-year and recipient year interactions.

\section{B. Selection on the Dependent Variable}

Due to the log-transformation, the results presented so far relate only to recipient countries that have already received aid from a donor. To rule out selection effects, we thus include donor-recipient pairs without previous aid flows, allowing us to test whether leader change can even lead to the establishment of new development cooperation between a developing

\footnotetext{
${ }^{28}$ If we include the residuals of the interaction terms, which is not necessary in a control function, we obtain the same coefficients as in column 1.
} 
and a G7 country or to the complete abandonment of it, respectively.

We estimate an onset specification, in which the dependent variable is a dummy that is 1 if a country receives a positive amount of ODA commitments and zero otherwise (see Table 6, column 1). The sample consists only of donor-recipient dyads where there have been no prior ODA commitments. Concerning our variables of interest, only donor leader change has a statistically significant effect on the establishment of development cooperation with new recipient countries if voting alignment stays constant. Most importantly, the interaction terms are not statistically significant. Political convergence after leadership turnover does not induce development cooperation. We further test whether there is complete abandonment of development cooperation between a donor and a recipient induced by alignment change after leader turnover (see Table 5, column 2). In this specification, none of the core variables is statistically significant. Hence, we conclude that the voting alignment mechanism after leadership change has no effect on the establishment or abandonment of development cooperation between donors and recipients.

Although we find no selection effects, we replicate columns 3 and 4 from Table 2 including zero ODA commitments (see Table 6, columns 3 and 4). ${ }^{29}$ The main results support our argument. Nevertheless, the substantive as well as statistical significance decreases compared to the results in Table 2. This is however not surprising. If the interaction of leader change and the political alignment does not have an effect on the extensive margin, including zeros biases the results for the intensive margins downward. Thus, foreign policy realignment is only consequential for recipients that already have established development cooperation.

\section{Alignment and ODA Measures}

In a next step, we test if our results are driven by the measurement of foreign policy realignment. First, we employ regular votes instead of all votes. This measure is based on recurring votes and therefore not dependent on the yearly fluctuations of the UNGA voting agenda (Bailey et al., 2015; Häge and Hug, 2016). Second, we focus only on key

\footnotetext{
${ }^{29}$ In order to log-transform this variable, we add $\$ 1$ to each observation.
} 
TABLE 6

ODA Selection and Zero ODA Commitments

\begin{tabular}{|c|c|c|c|c|}
\hline & \multicolumn{4}{|c|}{ Dependent variable: } \\
\hline & $\begin{array}{l}\text { ODA onset } \\
\text { (1) }\end{array}$ & $\begin{array}{c}\text { ODA cont. } \\
(2)\end{array}$ & $\begin{array}{c}\ln O D A \\
(3)\end{array}$ & $\begin{array}{c}\text { commitments } \\
\text { (4) }\end{array}$ \\
\hline \multirow[t]{2}{*}{ Recipient change } & 0.022 & 0.002 & $-0.049^{* *}$ & \\
\hline & $(0.014)$ & $(0.003)$ & $(0.020)$ & \\
\hline \multirow[t]{2}{*}{ Donor change } & $0.022 * *$ & -0.001 & $0.029^{*}$ & \\
\hline & $(0.010)$ & $(0.004)$ & $(0.017)$ & \\
\hline \multirow[t]{2}{*}{ Alignment change } & -0.062 & -0.007 & $0.313^{* *}$ & 0.193 \\
\hline & $(0.076)$ & $(0.024)$ & $(0.145)$ & $(0.206)$ \\
\hline \multirow[t]{2}{*}{ Recipient change $*$ realignment } & -0.187 & 0.050 & $0.500^{*}$ & $0.788^{* *}$ \\
\hline & $(0.184)$ & $(0.055)$ & $(0.275)$ & $(0.312)$ \\
\hline \multirow[t]{2}{*}{ Donor change $*$ realignment } & -0.006 & 0.016 & 0.356 & 0.184 \\
\hline & $(0.114)$ & $(0.042)$ & $(0.220)$ & $(0.249)$ \\
\hline \multirow[t]{2}{*}{ Last year alignment } & $-0.344^{* * *}$ & -0.022 & $0.727^{* * *}$ & $0.676^{* *}$ \\
\hline & $(0.103)$ & $(0.026)$ & $(0.211)$ & $(0.339)$ \\
\hline \multirow{2}{*}{ Past mean alignment } & $0.197^{* *}$ & -0.029 & $0.681^{* * *}$ & $0.427^{*}$ \\
\hline & $(0.100)$ & $(0.030)$ & $(0.187)$ & $(0.249)$ \\
\hline \multirow{2}{*}{$\overline{\text { Donor GDP }(\ln )}$} & $0.116^{*}$ & -0.009 & $1.358^{* * *}$ & \\
\hline & $(0.065)$ & $(0.025)$ & $(0.426)$ & \\
\hline \multirow{2}{*}{ Donor population (ln) } & 0.189 & $0.181^{* * *}$ & $1.338^{*}$ & \\
\hline & $(0.224)$ & $(0.060)$ & $(0.697)$ & \\
\hline \multirow[t]{2}{*}{ Recipient GDP (ln) } & -0.026 & -0.011 & -0.094 & \\
\hline & $(0.021)$ & $(0.009)$ & $(0.085)$ & \\
\hline \multirow[t]{2}{*}{ Recipient population (ln) } & -0.029 & -0.011 & 0.179 & \\
\hline & $(0.045)$ & $(0.020)$ & $(0.200)$ & \\
\hline Adjusted R-squared & 0.013 & 0.004 & 0.053 & 0.843 \\
\hline Fixed Effects & $\mathrm{DR}, \mathrm{Y}$ & $\mathrm{DR}, \mathrm{Y}$ & $\mathrm{DR}, \mathrm{Y}$ & DR,RY,DY \\
\hline \# of observations & 4745 & 16938 & 21683 & 24176 \\
\hline \# of dyads & 426 & 673 & 745 & 768 \\
\hline
\end{tabular}

Leader change variables in column 4 omitted due to fixed effects.

Fixed effects: donor-recipient (DR), year (Y), recipient-year (RY), donor-year (DY)

Robust standard errors in parentheses, clustered on donor-recipient dyad.

Significance levels: $* * * \mathrm{p}<0.01,{ }^{* *} \mathrm{p}<0.05,{ }^{*} \mathrm{p}<0.1$.

votes - i.e., votes deemed important by the US State Department - to test if recipients and donors act differently to issues considered as strategically important by the United States (Kersting and Kilby, 2016). Third, we test if our results are driven by extreme shifts in foreign policy and run a trimmed least squares regression dropping the bottom and top $5 \%$ of the voting change observations. Lastly, we include vote abstentions into the UNGA voting alignment counting abstentions .5 (Barro and Lee, 2005).

The results largely support the robustness of the previous findings (see Table 7). The interaction between recipient leader change and the change in voting alignment is 
TABLE 7

Alternative Alignment Change Specifications

\begin{tabular}{|c|c|c|c|c|c|}
\hline & \multicolumn{5}{|c|}{ Dependent variable: $\ln O D A$ commitments } \\
\hline & \multirow{2}{*}{$\begin{array}{c}\text { Regular votes } \\
\text { (1) }\end{array}$} & \multirow{2}{*}{$\begin{array}{c}\text { Key votes } \\
(2)\end{array}$} & \multirow{2}{*}{$\begin{array}{c}\text { TLS 10\% } \\
(3)\end{array}$} & \multicolumn{2}{|c|}{ Vote abstentions } \\
\hline & & & & $(4)$ & $(5)$ \\
\hline \multirow[t]{2}{*}{ Recipient change } & $-0.091^{* * *}$ & $-0.069^{* *}$ & $-0.094^{* * *}$ & $-0.101^{* * *}$ & \\
\hline & $(0.032)$ & $(0.034)$ & $(0.033)$ & $(0.032)$ & \\
\hline \multirow[t]{2}{*}{ Donor change } & $0.048^{*}$ & $0.065^{* *}$ & $0.058^{* *}$ & $0.046^{*}$ & \\
\hline & $(0.027)$ & $(0.027)$ & $(0.027)$ & $(0.027)$ & \\
\hline \multirow[t]{2}{*}{ Alignment change } & 0.320 & $0.630^{* * *}$ & -0.142 & -0.058 & 0.058 \\
\hline & $(0.200)$ & $(0.099)$ & $(0.305)$ & $(0.294)$ & $(0.460)$ \\
\hline \multirow[t]{2}{*}{ Recipient change ${ }^{*}$ realignment } & $1.208^{* * *}$ & -0.075 & $1.217^{* *}$ & $1.646^{* * *}$ & $1.283^{*}$ \\
\hline & $(0.399)$ & $(0.141)$ & $(0.616)$ & $(0.539)$ & $(0.681)$ \\
\hline \multirow[t]{2}{*}{ Donor change $*$ realignment } & $0.943^{* * *}$ & $0.325^{* *}$ & $2.970 * * *$ & $0.972^{* *}$ & 0.471 \\
\hline & $(0.334)$ & $(0.158)$ & $(0.522)$ & $(0.457)$ & $(0.629)$ \\
\hline \multirow[t]{2}{*}{ Last year alignment } & $1.341^{* * *}$ & $1.153^{* * *}$ & $0.928^{* *}$ & 0.595 & 0.984 \\
\hline & $(0.309)$ & $(0.160)$ & $(0.394)$ & $(0.443)$ & $(0.784)$ \\
\hline \multirow[t]{2}{*}{ Past mean alignment } & $0.970 * *$ & -0.064 & $0.987^{* * *}$ & $0.882^{* *}$ & 0.699 \\
\hline & $(0.390)$ & $(0.177)$ & $(0.328)$ & $(0.387)$ & $(0.614)$ \\
\hline \multirow[t]{2}{*}{ Log GDP recipient } & $2.225^{* * *}$ & $2.121^{* * *}$ & $2.479 * * *$ & $2.309^{* * *}$ & \\
\hline & $(0.647)$ & $(0.678)$ & $(0.613)$ & $(0.652)$ & \\
\hline \multirow[t]{2}{*}{ Log GDP donor } & -0.074 & $2.226^{*}$ & 0.299 & -0.109 & \\
\hline & $(1.018)$ & $(1.269)$ & $(1.020)$ & $(1.028)$ & \\
\hline \multirow[t]{2}{*}{ Log population recipient } & -0.131 & 0.013 & -0.071 & -0.137 & \\
\hline & $(0.132)$ & $(0.139)$ & $(0.142)$ & $(0.133)$ & \\
\hline \multirow[t]{2}{*}{ Log population donor } & $0.799^{* *}$ & 0.606 & $0.842^{* *}$ & $0.804^{* *}$ & \\
\hline & $(0.341)$ & $(0.368)$ & $(0.351)$ & $(0.343)$ & \\
\hline Adjusted R-squared & 0.044 & 0.053 & 0.048 & 0.041 & 0.786 \\
\hline Fixed Effects & $\mathrm{DR}, \mathrm{Y}$ & $\mathrm{DR}, \mathrm{Y}$ & $\mathrm{DR}, \mathrm{Y}$ & $\mathrm{DR}, \mathrm{Y}$ & DR,RY,DY \\
\hline \# of observations & 16900 & 13861 & 15315 & 16928 & 18571 \\
\hline \# of dyads & 662 & 661 & 668 & 668 & 681 \\
\hline
\end{tabular}

Regular votes (reoccurring votes) in column 1.

Key votes in column 2 .

Top and bottom $5 \%$ of realignment excluded in columns 3 .

Signal includes vote abstentions in columns 4 and 5 .

Leader change variables in column 5 omitted due to fixed effects.

Fixed effects: donor-recipient (DR), year (Y), recipient-year (RY), donor-year (DY)

Robust standard errors in parentheses, clustered on donor-recipient dyad.

Significance levels: ${ }^{* * *} \mathrm{p}<0.01,{ }^{* *} \mathrm{p}<0.05,{ }^{*} \mathrm{p}<0.1$.

positive and statistically significant in all but one model. Only in case of key votes is the coefficient not statistically significant. At first sight this might seem puzzling. Yet, key votes are based on votes deemed important by the United States and might therefore always carry consequences, as suggested by the alignment change coefficient. The donor interaction effect in turn might be driven by the fact that other G7 leaders follow the US to different degrees. Furthermore, key votes often cluster around certain events, like 
TABLE 8

Net ODA disbursements

\begin{tabular}{lcccc}
\hline \hline & \multicolumn{3}{c}{ Dependent variable: Log net ODA } & disbursements \\
& $(1)$ & $(2)$ & $(3)$ & $(4)$ \\
\hline Recipient change & $-0.070^{* *}$ & & $-0.066^{* *}$ & \\
& $(0.029)$ & & $(0.029)$ & \\
Donor change & $0.065^{* * *}$ & & $0.073^{* * *}$ & \\
& $(0.022)$ & & $(0.023)$ & \\
Alignment change & & $0.389^{* *}$ & 0.077 & 0.468 \\
& & $(0.188)$ & $(0.207)$ & $(0.326)$ \\
Recipient change ${ }^{*}$ realignment & & & $0.798^{* *}$ & $0.785^{*}$ \\
& & & $(0.389)$ & $(0.445)$ \\
Donor change * realignment & & & $0.701^{* *}$ & 0.153 \\
& & & $(0.308)$ & $(0.469)$ \\
Last year alignment & $0.675^{* * *}$ & $1.000^{* * *}$ & $0.835^{* * *}$ & $1.246^{* *}$ \\
& $(0.200)$ & $(0.303)$ & $(0.305)$ & $(0.528)$ \\
Past mean alignment & $0.671^{* *}$ & $0.488^{*}$ & $0.663^{* *}$ & 0.692 \\
& $(0.262)$ & $(0.273)$ & $(0.291)$ & $(0.430)$ \\
\hline Adjusted R-squared & 0.052 & 0.051 & 0.052 & 0.811 \\
Fixed Effects & $\mathrm{DR}, \mathrm{Y}$ & $\mathrm{DR}, \mathrm{Y}$ & $\mathrm{DR}, \mathrm{Y}$ & $\mathrm{DR}, \mathrm{RY}, \mathrm{DY}$ \\
\# of observations & 15853 & 15853 & 15853 & 17218 \\
\# of dyads & 661 & 661 & 661 & 670 \\
\hline \hline
\end{tabular}

Leader change variables in column 4 are omitted due to fixed effects.

Columns 1 to 3 include GDP and population controls for donors and recipients.

Fixed effects: donor-recipient (DR), year (Y), recipient-year (RY), donor-year (DY)

Robust standard errors in parentheses, clustered on donor-recipient dyad.

Significance levels: $* * * \mathrm{p}<0.01,{ }^{* *} \mathrm{p}<0.05,{ }^{*} \mathrm{p}<0.1$.

the Iraq War. Recipient country leaders might come to power and, simply by chance, not be able to signal alignment via key votes. ${ }^{30}$ The interaction between donor leader change and the foreign policy alignment change is positive and statistically significant as long as we do not count abstentions. All in all, we find our results not to be driven by strong changes in voting alignment and robust to the different measures of UNGA voting alignment.

Next, we check if our results are only driven by changing ODA commitments decisions or if they also hold for actual ODA disbursements. Thus we replicate Table 2 using net ODA disbursements instead of ODA commitments. Table 8 shows that our

\footnotetext{
${ }^{30}$ Since key votes are solely determined by the US, we rerun column 2 using only the US as a donor and utilize a simple time trend instead of the year fixed effects. In this case both interactions lose their statistical significance while yearly alignment changes enter significant (results not reported). This is not to surprising, since Carter and Stone (2015) have shown that the US use aid to influence voting behavior on key votes, thus introducing problems of endogeneity.
} 
obtained effects largely hold for aid disbursements as well, although the point coefficients become smaller and have reduced statistical significance. Note that the donor leader change interaction loses it's statistical significance in the gravity model in column 4 .

\section{Differences between Donors and Recipients}

There is ample evidence that donors differ in the way they disburse aid (Alesina and Dollar, 2000; Dietrich, 2016). The United States are famous for using aid to achieve geostrategic goals, while France focuses prominently on former colonies. Closely related to this is the question whether changes in the aid commitments of individual donors are due to the changes in the average alignment with the G7 in general or if the results are truly driven by the dyad-specific changes in political proximity. We test the two issues jointly by including the average change in voting alignment with the G7 as an additional control and fully interacting our baseline model for the different donors (see Table 9). ${ }^{31}$

Regarding the interaction between recipient change and foreign policy alignment, we find that Canada, Germany, Great Britain, and the United States are the main drivers behind the reward and punishment mechanism following recipient leader change. ${ }^{32}$ In case of alignment changes after donor leader change, we find statistically significant results for Canada, Germany, Great Britain, and Japan, while the rest of the G7 donors seem to exhibit no such behavior. France does not react to realignment after leader change, which is consistent with France's focus on former colonies (Alesina and Dollar, 2000). Despite not reacting to conditional signaling, Italy nevertheless goes along with the rest of the G7; the effect of average G7 realignment is positive and statistically significant. Although we do not find the same effects for every donor, we also do not find evidence against our theoretical argument. None of the interaction terms are negative and statistically significant. Rather, the results emphasize that different donors seem to vary with regards to the importance they place on realignment after leadership turnover. Most importantly,

\footnotetext{
${ }^{31}$ Note that we keep the time dummies separate, since they would overload the specification and absorb the donor change variable. Hence they only control for global shocks concerning all donors and recipients.

${ }^{32}$ This is surprising since both the UK and the US have been shown to have a tendency to bypass aid in the first place (Dietrich, 2016), which should make them less responsive to our proposed mechanism.
} 


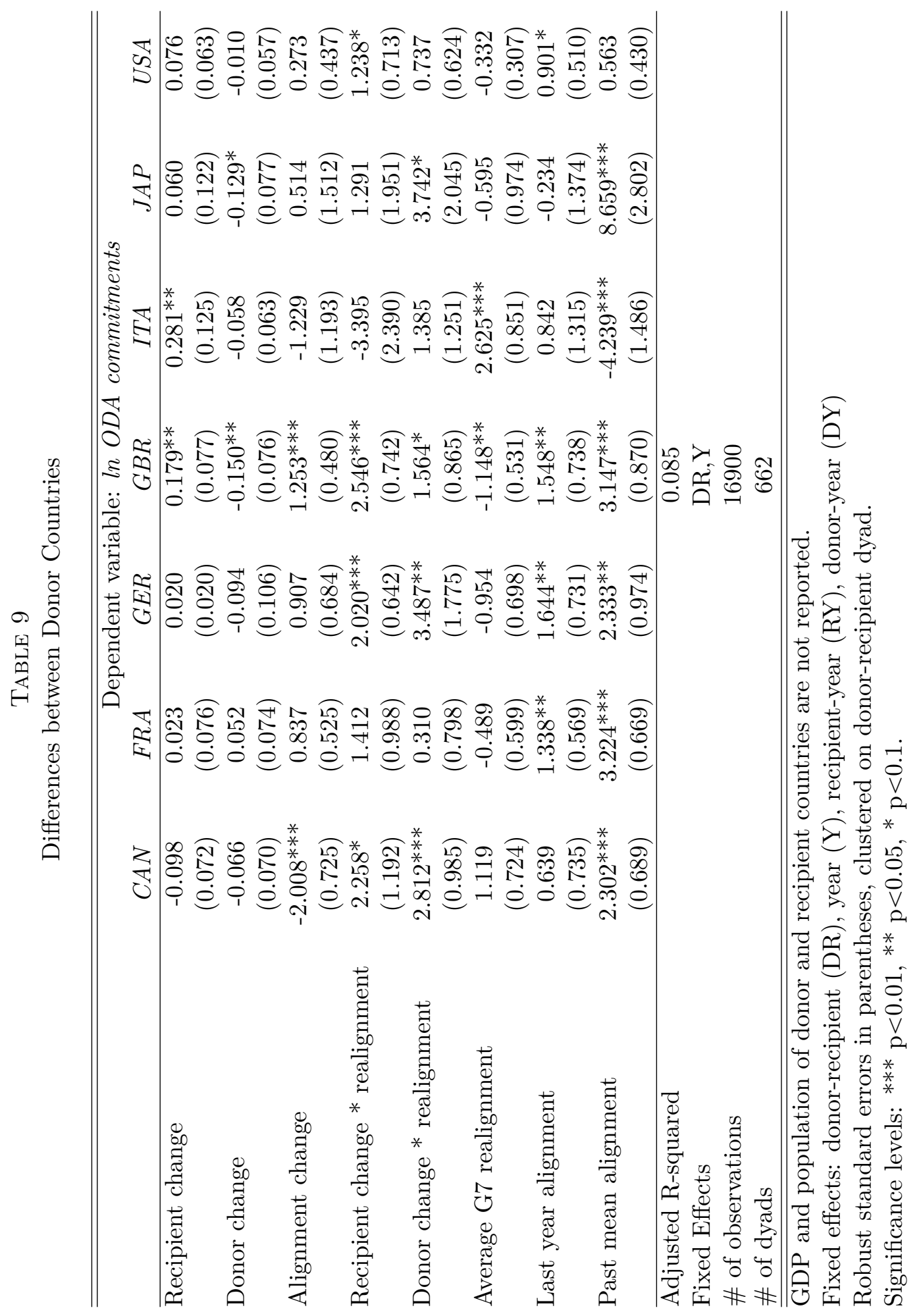


the results are not driven by a single donor.

To further check if single recipients drive our results, we perform leave-one-out tests. Here, we rerun our specification from column 4 in Table 2 excluding every recipient country once at a time. The point estimates of the recipient change-alignment interaction are plotted in Figure A-1 in the appendix. All effects are positive and statistically significant. From this we can conclude that no single donor has enough leverage to drive our main finding. Additionally, Figure A-2 plots the corresponding donor change-alignment interaction. Apart from two exceptions, the results remain stable.

Summing up, our results are robust to a variety of specifications. We show that reverse causality, selection effects, and the measurement of political alignment do not conflate our results in a substantive way. Donor countries reward recipients with higher ODA commitments, if they come closer to their own position on internationally relevant and important policies. To the contrary, recipients that show political animosity after leader change are confronted with substantial aid cuts.

\section{Conclusion}

In this study, we analyze a new mechanism through which big donors induce political aid cycles in recipient countries. We argue that donors place higher scrutiny on recipients' behavior in the UNGA after both donor and recipient leader change. In the aftermath of leadership turnover, otherwise inconsequential yearly fluctuations in voting alignment between recipients and donors lead to substantial effects on aid commitments.

We find that new recipient leaders that converge to a donor during their first year in office receive substantially more aid commitments compared to those that diverge from positions that donors take in the UNGA. We consistently find this conditional alignment effect in case of both recipient and donor leader change. The substantial size of the effect differs, however. While new recipient leaders mainly face the prospect of sizable cutbacks in case they dis-align from a donor, stronger alignment towards a new donor leader is seemingly an important strategy to increase ODA commitments. For the bulk of the alignment changes following leader change (around 78\%) cutbacks range between $9.7 \%$ 
and $19.6 \%$ for dis-aligning new recipient leaders and amount to between $3.8 \%$ and $9.1 \%$ in increases for recipients that align themselves with a new donor leader.

Moreover, aid increases after leader change are only short term as the alignment effect vanishes two years after leader change. Hence, initial changes in foreign policy of a new recipient leader - the first impression - determine the bilateral aid provision that a recipient country will receive from its donors only in the short term. We conclude that new recipient leaders must warily consider their first appearance on the international stage at the beginning of their incumbency. As donors put their foreign policy positions under increased scrutiny, usually inconsequential changes in foreign policy result in sizable alterations of their aid commitments.

We provide evidence of an important mechanism explaining the volatility of development aid, beyond the effect of elections (Faye and Niehaus, 2012) or political importance due to temporary membership in the UNSC (Kuziemko and Werker, 2006). Politically motivated aid has been shown to be less effective in promoting growth (Dreher et al., 2016) and politically committed aid increases aid volatility that induces a heightened risk of civil conflict (Nielsen et al., 2011). Our results thus highlight that more scrutiny is required to dis-entangle development aid from politically motivated side payments that may have detrimental effects for developing countries. 


\section{References}

Alesina, A. and D. Dollar (2000). Who Gives Foreign Aid to Whom and Why? Journal of Economic Growth 5(1), 33-63.

Andersen, T. B., H. Hansen, and T. Markussen (2006). US Politics and World Bank IDA-Lending. Journal of Development Studies 42(5), 772-794.

Angrist, J. D. and J.-S. Pischke (2008). Mostly Harmless Econometrics: An Empiricist's Companion. Princeton University Press.

Annen, K. and S. Strickland (2017). Global Samaritans? Donor Election Cycles and the Allocation of Humanitarian Aid. European Economic Review Forthcoming.

Bailey, M. A., A. Strezhnev, and E. Voeten (2015). Estimating Dynamic State Preferences from United Nations Voting Data. Journal of Conflict Resolution FirstView(August $17,2015)$.

Barro, R. J. and J. W. Lee (2005). IMF Programs: Who Is Chosen and What Are the Effects? Journal of Monetary Economics 52(7), 1245-1269.

Beck, T., G. Clarke, A. Groff, P. Keefer, and P. Walsh (2001). New Tools in Comparative Political Economy: The Database of Political Institutions. World Bank Economic Review 15(1), 165-176.

Berger, D., W. Easterly, N. Nunn, and S. Satyanath (2013). Commercial Imperialism? Political Influence and Trade during the Cold War. American Economic Review 103(2), 863-896.

Bueno de Mesquita, B. and A. Smith (2010). The Pernicious Consequences of UN Security Council Membership. Journal of Conflict Resolution 54(5), 667-686.

Bueno de Mesquita, B., A. Smith, R. M. Siverson, and J. D. Morrow (2003). The Logic of Political Survival. Cambridge: MIT Press.

Bun, M. and T. Harrison (2014). OLS and IV Estimation of Regression Models Including Endogenous Interaction Terms. UvA-Econometrics Working Papers 14-02, Universiteit van Amsterdam, Department of Econometrics. 
Cameron, A. C., J. B. Gelbach, and D. L. Miller (2011). Robust Inference With Multiway Clustering. Journal of Business \& Economic Statistics 29(2), 238-249.

Carter, D. B. and R. W. Stone (2015). Democracy and Multilateralism: The Case of Vote Buying in the UN General Assembly. International Organization 69(1), 1-33.

Choi, I. (2001). Unit Root Tests for Panel Data. Journal of International Money and Finance 20(2), 249-272.

CIDA (2010). Canada's Aid Effectiveness Agenda. Focusing on Results. In http://publications.gc.ca/site/eng/396118/publication.html. Canadian International Development Agency.

Collier, P. and D. Dollar (2002). Aid Allocation and Poverty Reduction. European Economic Review 46(8), 1475-1500.

Dietrich, S. (2016). Donor Political Economies and the Pursuit of Aid Effectiveness. International Organization $70(1), 65-102$.

Dippel, C. (2015). Foreign Aid and Voting in International Organizations: Evidence from the IWC. Journal of Public Economics 132, 1-12.

Dreher, A., V. Eichenauer, and K. Gehring (2016). Geopolitics, Aid and Growth: The Impact of UN Security Council Membership on the Effectiveness of Aid. World Bank Economic Review FirstView(July 31, 2016).

Dreher, A. and N. M. Jensen (2007). Independent Actor or Agent? An Empirical Analysis of the Impact of U.S. Interests on International Monetary Fund Conditions. Journal of Law and Economics 50(1), 105-124.

Dreher, A. and N. M. Jensen (2013). Country or Leader? Political Change and UN General Assembly Voting. European Journal of Political Economy 29(3), 183-196.

Dreher, A. and J.-E. Sturm (2012). Do the IMF and the World Bank Influence Voting in the UN General Assembly? Public Choice 151(1-2), 363-397.

Dreher, A., J.-E. Sturm, and J. R. Vreeland (2009a). Development Aid and International Politics: Does Membership on the UN Security Council Influence World Bank De- 
cisions? Journal of Development Economics 88(1), 1-18.

Dreher, A., J.-E. Sturm, and J. R. Vreeland (2009b). Global Horse Trading: IMF Loans for Votes in the United Nations Security Council. European Economic Review 53(7), $742-757$.

Drukker, D. M. (2003). Testing for Serial Correlation in Linear Panel-Data Models. Stata Journal 3(2), 168-177.

Encyclopaedia Britannica (2017). John Evans Atta Mills. In https://www.britannica.com/biography/John-Evans-Atta-Mills.

Faye, M. and P. Niehaus (2012). Political Aid Cycles. American Economic Review 102(7), $3516-3530$.

Fearon, J. D. (1995). Rationalist Explanation for War. International Organization 49(3), $379-414$

Fearon, J. D. (1997). Signaling Foreign Policy Interests. Journal of Conflict Resolution 41(1), 68-90.

Gibler, D. M. (2009). International Military Alliances, 1648-2008. Washington D.C.: CQ Press.

Global Affairs Canada (2015). Ghana-Canada: Mutual Accountability Framework for Development Cooperation. In http://www.international.gc.ca/developmentdeveloppement/countries-pays/cadre-ghana-canada-framework.aspx?lang=eng. Government of Canada.

Goemans, H. E., K. S. Gleditsch, and G. Chiozza (2009). Introducing Archigos: A Dataset of Political Leaders. Journal of Peace Research 46(2), 269-283.

Häge, F. and S. Hug (2016). Consensus Decisions and Similarity Measures in International Organizations. International Interactions 42(3), 503-529.

Head, K. and T. Mayer (2014). Gravity Equations: Workhorse, Toolkit, and Cookbook. In G. Gopinath, E. Helpman, and K. Rogoff (Eds.), Handbook of International Economics, pp. 131-195. Amsterdam: Elsevier. 
Helpman, E. (1987). Imperfect Competition and International Trade: Evidence from Fourteen Industrial Countries. Journal of the Japanese and international economies 1(1), 62-81.

Heston, A., R. Summers, and B. Aten (2012). Penn World Table Version 7.1. In University of Pennsylvania.

Hillman, A. L. and N. Potrafke (2015). The UN Goldstone Report and Retraction: An Empirical Investigation. Public Choice 163(3-4), 247-266.

Hsiang, S. and A. Jina (2014). The Causal Effect of Environmental Catastrophe on Long-run Economic Growth: Evidence from 6,700 Cyclones. National Bureau of Economic Research 20352.

Hyde, S. D., N. Marinov, and V. Troeger (2012). Which Elections Can Be Lost? Political Analysis 20(2), 191-210.

Jones, B. F. and B. A. Olken (2005). Do Leaders Matter? National Leadership and Growth Since World War II. Quarterly Journal of Economics 120(3), 835-864.

Jones, B. F. and B. A. Olken (2009). Hit or Miss? The Effect of Assassinations on Institutions and War. American Economic Journal: Macroeconomics 1(2), 55-87.

Kersting, E. K. and C. Kilby (2016). With a Little Help from My Friends: Global Electioneering and World Bank Lending. Journal of Development Economics 121, $153-165$.

Kilby, C. (2009). Donor Influence in International Financial Institutions: Deciphering What Alignment Measures Measure. In Political Economy of International Organizations Meeting. Geneva.

Kuziemko, I. and E. Werker (2006). How Much Is a Seat on the Security Council Worth? Foreign Aid and Bribery at the United Nations. Journal of Political Economy 114(5), 905-930.

Marshall, M., T. Gurr, and K. Jaggers (2016). Polity IV Project. Political Regime Characteristics and Transitions, 1800-2015. In Center for Systemic Peace. 
Mattes, M., B. A. Leeds, and R. Carroll (2015). Leadership Turnover and Foreign Policy Change: Societal Interests, Domestic Institutions, and Voting in the United Nations. International Studies Quarterly 59(3), 280-290.

McGillivray, F. and A. Smith (2004). The Impact of Leadership Turnover on Trading Relations Between States. International Organization 58(3), 567-600.

Moravcsik, A. (1997). Taking Preferences Seriously: A Liberal Theory of International Politics. International Organization 51(4), 513-553.

New York Times (2009). Obama's Speech in Cairo, June 4, 2009. In http://www.nytimes.com/2009/06/04/us/politics/04obama.text.html?_r=2.

Nielsen, R. A., M. G. Findley, Z. S. Davis, T. Candland, and D. L. Nielson (2011). Foreign Aid Shocks as a Cause of Violent Armed Conflict. American Journal of Political Science 55(2), 219-232.

OECD (2015). Official Development Assistance - Definition and Coverage. In http://www.oecd.org/dac/stats/officialdevelopmentassistancedefinitionand coverage.htm\#Definition.

Potrafke, N. (2017). Partisan Politics: The Empirical Evidence from OECD Panel Studies. Journal of Comparative Economics forthcoming.

Putnam, R. D. (1988). Diplomacy and Domestic Politics: The Logic of Two-Level Games. International Organization 42(3), 427-460.

Teorell, J., N. Charron, S. Dahlberg, S. Holmberg, B. Rothstein, P. Sundin, and R. Svensson (2013). The Quality of Government Dataset, version 20dec13. Technical report, The Quality of Government Institute. University of Gothenburg.

Thacker, S. C. (1999). The High Politics of IMF Lending. World Politics 52(1), 38-75.

UN Comtrade (2017). International Trade Statistics Database. In https://comtrade.un.org.

Voeten, E. (2000). Clashes in the Assembly. International Organization 54(2), 185-215.

Voeten, E. (2004). Resisting the Lonely Superpower: Responses of States in the United 
Nations to U.S. Dominance. Journal of Politics 66(3), 729-754.

Voeten, E., A. Strezhnev, and M. Bailey (2009). United Nations General Assembly Voting Data. In http://hdl.handle.net/1902.1/12379. Harvard Dataverse.

Vreeland, J. and A. Dreher (2014). The Political Economy of the United Nations Security Council. Money and Influence. Cambridge: Cambridge University Press.

Wooldridge, J. M. (2010). Econometric Analysis of Cross Section and Panel Data. Cambridge: MIT Press.

Wooldridge, J. M. (2015). Control Function Methods in Applied Econometrics. Journal of Human Resources 50(2), 420-445. 


\section{Appendix}

Figure A-1

Leave-one-out Test for Recipient Change Interaction
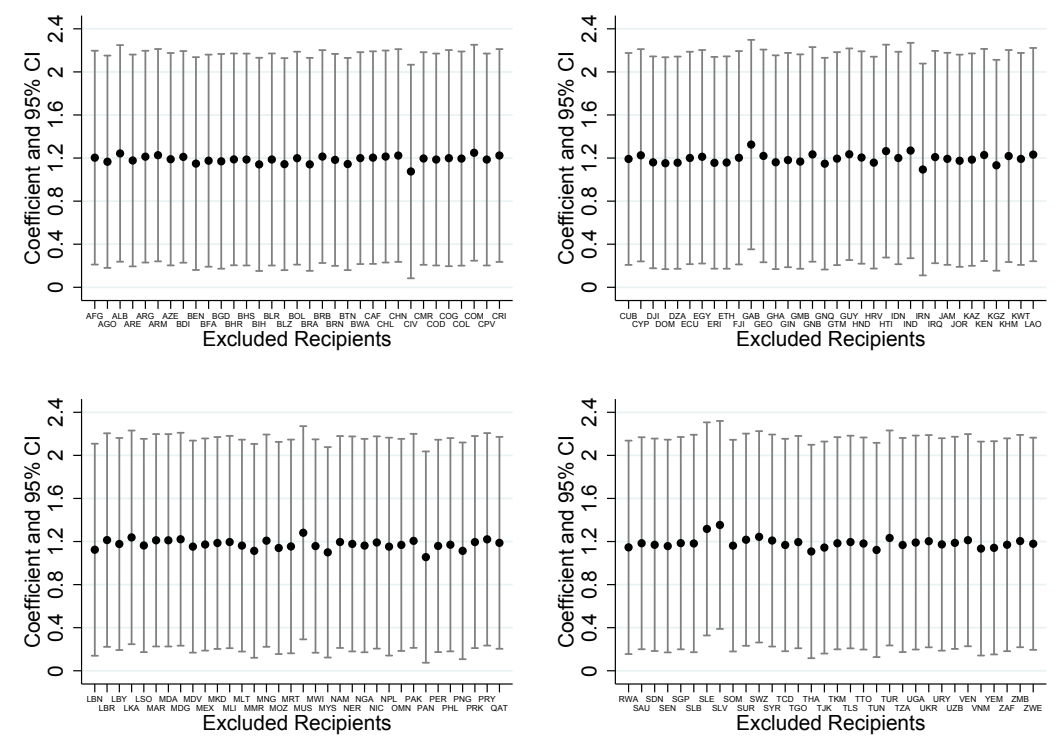

Note: Reported are point coefficients of the interaction between recipient change and alignment change and the corresponding 95\% confidence intervals, based on column 4 in Table 2 .

Figure A-2

Leave-one-out Test for Donor Change Interaction
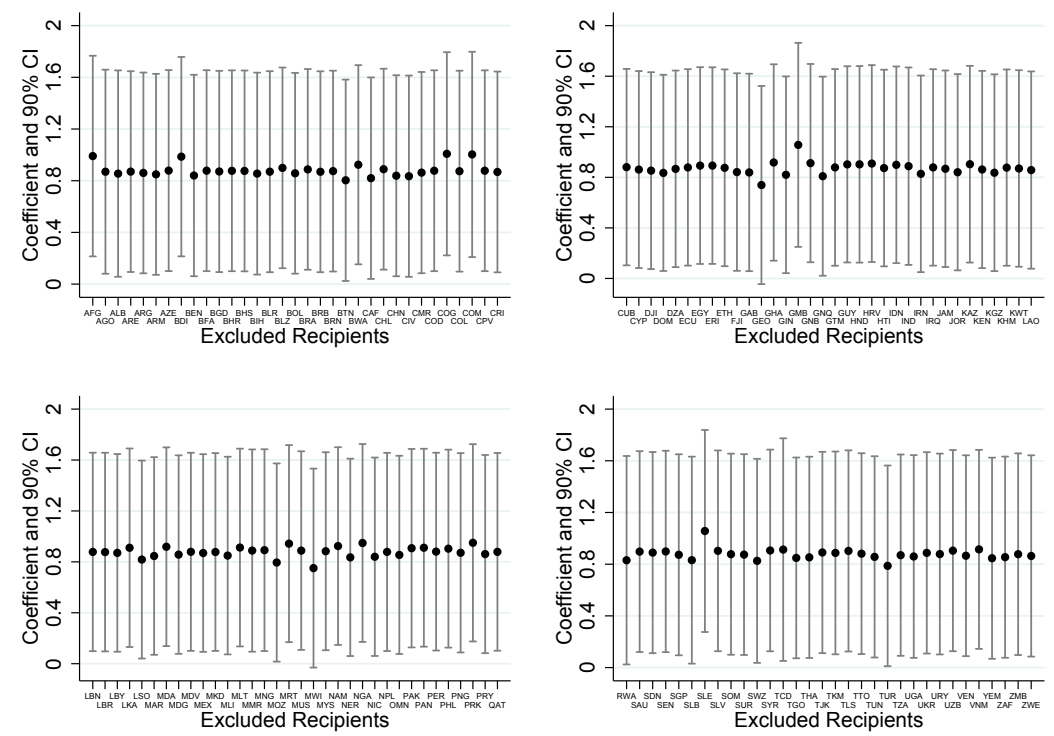

Note: Reported are point coefficients of the interaction between donor change and alignment change and the corresponding $90 \%$ confidence intervals, based on column 4 in Table 2 . 
TABLE A-1

List of Recipient Countries, in Alphabetical Order

Afghanistan, Albania, Algeria, Angola, Argentina, Armenia, Azerbaijan, Bahamas, Bahrain, Bangladesh, Barbados, Belarus, Belize, Benin, Bhutan, Bolivia, Bosnia and Herzegovina, Botswana, Brazil, Brunei Darussalam, Burkina Faso, Burundi, Cambodia, Cameroon, Central African Republic, Chad, Chile, China, Colombia, Comoros, Congo-Brazzaville, Costa Rica, Croatia, Cuba, Cyprus, Djibouti, Dominican Republic, Ecuador, Egypt, El Salvador, Equatorial Guinea, Eritrea, Ethiopia, Fiji, Gabon, Gambia, Georgia, Ghana, Guatemala, Guinea, GuineaBissau, Guyana, Haiti, Honduras, India, Indonesia, Iran, Iraq, Ivory Coast, Jamaica, Jordan, Kazakhstan, Kenya, Korea (North), Kuwait, Kyrgyzstan, Laos, Lebanon, Lesotho, Liberia, Libya, Madagascar, Malawi, Malaysia, Maldives, Mali, Malta, Mauritania, Mauritius, Mexico, Moldova, Mongolia, Morocco, Mozambique, Myanmar, Namibia, Nepal, Nicaragua, Niger, Nigeria, Oman, Pakistan, Panama, Papua New Guinea, Paraguay, Peru, Philippines, Qatar, Rwanda, Saudi Arabia, Senegal, Serbia, Sierra Leone, Singapore, Solomon Islands, Somalia, South Africa, Sri Lanka, Sudan, Suriname, Swaziland, Syria, Tajikistan, Tanzania, Thailand, Timor-Leste, Togo, Trinidad and Tobago, Tunisia, Turkey, Turkmenistan, Uganda, Ukraine, United Arab Emirates, Uruguay, Uzbekistan, Venezuela, Vietnam, Yemen, Zambia, Zimbabwe.

TABLE A-2

Descriptive Statistics

\begin{tabular}{lccccc}
\hline \hline & $\mathrm{N}$ & Min & Mean & Max & SD \\
\hline ODA commitments & 18,571 & 0.01 & 67.49 & $19,721.40$ & 251.32 \\
ODA commitments (Log) & 18,571 & -4.61 & 2.18 & 9.89 & 2.37 \\
Administration dyads & 18,571 & 1.00 & - & 7,507 & - \\
Administration change & 18,571 & 0.00 & 0.27 & 1.00 & 0.44 \\
Recipient change & 18,571 & 0.00 & 0.13 & 1.00 & 0.34 \\
Donor change & 18,571 & 0.00 & 0.20 & 1.00 & 0.40 \\
Alignment change & 18,571 & -0.94 & -0.00 & 0.67 & 0.08 \\
Voting Alignment & 18,571 & 0.00 & 0.62 & 1.00 & 0.23 \\
Past mean voting alignment & 18,571 & 0.00 & 0.62 & 1.00 & 0.22 \\
Administration dyad duration & 18,571 & 1.00 & 5.93 & 16.00 & 3.65 \\
Donor GDP (log) & 17,401 & 20.09 & 21.45 & 23.30 & 0.81 \\
Recipient GDP (log) & 16,928 & 11.51 & 16.72 & 22.97 & 1.82 \\
Donor population (log) & 17,401 & 10.08 & 11.21 & 12.65 & 0.71 \\
Recipient population (log) & 17,095 & 4.95 & 9.06 & 14.10 & 1.70 \\
Similarity Index (GDP) & 16,928 & 0.00 & 0.06 & 0.50 & 0.11 \\
Similarity Index (Population) & 17,095 & 0.00 & 0.21 & 0.50 & 0.16 \\
(Donor) Imports in million USD (Log) & 18,571 & -13.82 & -2.88 & 13.00 & 8.99 \\
(Recipients) Imports in million USD (Log) & 18,571 & -13.82 & -5.58 & 12.13 & 9.42 \\
\hline \hline
\end{tabular}


TABLE A-3

Variables and Sources

\begin{tabular}{lc}
\hline \hline Variable & Source \\
\hline ODA commitments & OECD (2015) \\
ODA commitments (Log) & OECD (2015) \\
Administration dyads & Archigos (Goemans et al., 2009) \\
Administration change & Archigos (Goemans et al., 2009) \\
Recipient change & Archigos (Goemans et al., 2009) \\
Donor change & Archigos (Goemans et al., 2009) \\
Administration dyad duration & Archigos (Goemans et al., 2009) \\
Alignment change & Voeten et al. (2009) \\
Voting Alignment & Voeten et al. (2009) \\
Past mean voting alignment & Voeten et al. (2009) \\
Donor GDP (log) & PWT 7.1 (Heston et al., 2012) \\
Recipient GDP (log) & PWT 7.1 (Heston et al., 2012) \\
Donor population (log) & PWT 7.1 (Heston et al., 2012) \\
Recipient population (log) & PWT 7.1 (Heston et al., 2012) \\
(Donor) Imports in million USD (Log) & UN Comtrade (2017) \\
(Recipients) Imports in million USD (Log) & UN Comtrade (2017) \\
GDP per Capita (Log) & PWT 7.1 (Heston et al., 2012) \\
Democracy & Polity IV (Marshall et al., 2016) \\
Political System Transition & Polity IV (Marshall et al., 2016) \\
Military Alliance (United States) & Mattes et al. (2015) \\
Military Alliance (Russia) & Mattes et al. (2015) \\
Domestic Support Group Change (Donor) & Mattes et al. (2015) \\
Domestic Support Group Change (Recipient) & Mattes et al. (2015) \\
Same Political Colour Dummy & DPI (Beck et al., 2001) \\
Natural Death of a Leader (Recipient) & Jones and Olken (2005) \\
Executive Elections (Donor) & NELDA (Hyde et al., 2012) \\
Executive Elections (Recipient) & NELDA (Hyde et al., 2012) \\
Legislative Elections (Donor) & NELDA (Hyde et al., 2012) \\
Legislative Elections (Recipient) & NELDA (Hyde et al., 2012) \\
Presidential Term Limits (USA) & NELDA (Hyde et al., 2012) \\
\hline \hline & \\
\hline
\end{tabular}


TABLE A-4

Other Channels

\begin{tabular}{|c|c|c|c|c|c|}
\hline & \multicolumn{5}{|c|}{ Dependent variable: } \\
\hline & (1) & $(2)$ & $(3)$ & $(4)$ & (5) \\
\hline & ODA com. & ODA com. & ODA com. & Donor Imports & Recipient Imports \\
\hline \multirow[t]{2}{*}{ Alignment change } & -0.267 & 0.105 & 0.041 & -0.745 & -0.630 \\
\hline & $(0.306)$ & $(0.355)$ & $(0.349)$ & $(0.550)$ & $(0.449)$ \\
\hline \multirow[t]{2}{*}{ Recipient change ${ }^{*}$ realignment } & $0.954^{* *}$ & $1.096^{*}$ & $1.200^{* *}$ & -0.801 & 0.285 \\
\hline & $(0.455)$ & $(0.575)$ & $(0.502)$ & $(0.742)$ & $(0.416)$ \\
\hline \multirow[t]{2}{*}{ Donor change ${ }^{*}$ realignment } & $0.777^{*}$ & $0.832^{*}$ & $0.872^{*}$ & 0.548 & 0.480 \\
\hline & $(0.423)$ & $(0.501)$ & $(0.472)$ & $(0.605)$ & $(0.470)$ \\
\hline \multirow[t]{2}{*}{ Last year alignment } & 0.316 & $0.968^{*}$ & $0.951^{*}$ & -1.449 & $-1.269^{*}$ \\
\hline & $(0.391)$ & $(0.524)$ & $(0.530)$ & $(1.026)$ & $(0.729)$ \\
\hline \multirow[t]{2}{*}{ Past mean alignment } & $0.950^{* *}$ & 0.703 & $0.732^{*}$ & 0.275 & $1.207^{* *}$ \\
\hline & $(0.371)$ & $(0.446)$ & $(0.434)$ & $(0.562)$ & $(0.547)$ \\
\hline Lagged ODA commitments & $\begin{array}{c}0.338^{* * *} \\
(0.017)\end{array}$ & & & & \\
\hline Similarity Index (GDP) & & $\begin{array}{c}3.386 \\
(2.077)\end{array}$ & & & \\
\hline Similarity Index (Population) & & $\begin{array}{l}1.742 \\
(2.849)\end{array}$ & & & \\
\hline Donor Imports (Log) & & & $\begin{array}{c}0.015 \\
(0.010)\end{array}$ & & \\
\hline Recipient Imports (Log) & & & $\begin{array}{l}-0.006 \\
(0.009)\end{array}$ & & \\
\hline Adjusted R-squared & 0.813 & 0.790 & 0.786 & 0.975 & 0.986 \\
\hline Fixed Effects & DR,RY,DY & $\mathrm{DR}, \mathrm{RY}, \mathrm{DY}$ & DR,RY,DY & DR,RY,DY & DR,RY,DY \\
\hline \# of observations & 17858 & 16923 & 18571 & 18571 & 18571 \\
\hline \# of dyads & 673 & 663 & 681 & 681 & 681 \\
\hline
\end{tabular}

All dependent variables are log-transformed.

Fixed effects: donor-recipient (DR), year (Y), recipient-year (RY), donor-year (DY)

Robust standard errors in parentheses, clustered on donor-recipient dyad.

Significance levels: $* * * \mathrm{p}<0.01,{ }^{* *} \mathrm{p}<0.05,{ }^{*} \mathrm{p}<0.1$. 
TABLE A-5

Timing of the Conditional Alignment Effect

\begin{tabular}{|c|c|c|c|c|c|}
\hline \multirow{3}{*}{ Leader change-alignment interaction } & \multicolumn{5}{|c|}{ Dependent variable: $\ln O D A$ commitments } \\
\hline & 2 years & 1 year & leader & 1 year & 2 years \\
\hline & prior & prior & change & after & after \\
\hline \multirow[t]{2}{*}{ Alignment change } & $0.7876^{*}$ & 0.5832 & 0.0342 & 0.3903 & 0.5907 \\
\hline & $(0.4014)$ & $(0.3987)$ & $(0.3497)$ & $(0.3446)$ & $(0.3742)$ \\
\hline \multirow[t]{2}{*}{ Recipient change $*$ realignment } & 0.2464 & 0.5709 & $1.1865^{* *}$ & $0.8407^{*}$ & -0.3027 \\
\hline & $(0.4947)$ & $(0.5081)$ & $(0.5020)$ & $(0.5061)$ & $(0.5800)$ \\
\hline \multirow{2}{*}{ Donor change $*$ realignment } & -0.6419 & -0.1957 & $0.8773^{*}$ & $0.8859^{*}$ & 0.5312 \\
\hline & $(0.5046)$ & $(0.4626)$ & $(0.4723)$ & $(0.4949)$ & $(0.4921)$ \\
\hline \multirow[t]{2}{*}{ Last year alignment } & $1.3252^{* *}$ & $1.1019 *$ & $0.9370^{*}$ & $1.3890^{* *}$ & $1.5363^{* * *}$ \\
\hline & $(0.6232)$ & $(0.5932)$ & $(0.5288)$ & $(0.5431)$ & $(0.5779)$ \\
\hline \multirow{2}{*}{ Past mean alignment } & 0.1643 & 0.1839 & $0.7297^{*}$ & 0.2997 & 0.0633 \\
\hline & $(0.4321)$ & $(0.4198)$ & $(0.4342)$ & $(0.4201)$ & $(0.4092)$ \\
\hline Fixed Effects & DR,RY,DY & DR,RY,DY & DR,RY,DY & DR,RY,DY & DR,RY,DY \\
\hline Adjusted R-squared & 0.783 & 0.785 & 0.786 & 0.791 & 0.794 \\
\hline \# of observations & 17103 & 17858 & 18571 & 17322 & 16568 \\
\hline \# of dyads & 681 & 681 & 681 & 681 & 681 \\
\hline
\end{tabular}

Fixed effects: donor-recipient (DR), year (Y), recipient-year (RY), donor-year (DY)

Robust standard errors in parentheses, clustered on donor-recipient dyad.

Significance levels: ${ }^{* * *} \mathrm{p}<0.01,{ }^{* *} \mathrm{p}<0.05,{ }^{*} \mathrm{p}<0.1$.

TABLE A-6

Additional Variables in Table 3

\begin{tabular}{lll}
\hline \hline Specification & Variables & Source \\
\hline Mattes et al. (2015) & Democracy (if PolityIV $>=6)$ & Teorell et al. (2013) \\
& Political system transition & Teorell et al. (2013) \\
& USA defense pact & Gibler (2009) \\
& RUS defense pact & Gibler (2009) \\
\hline Dreher and Jensen (2013) & Donor GDP per capita & Heston et al. (2012) \\
& Recipient GDP per capita & Heston et al. (2012) \\
& Political color & Beck et al. (2001) \\
\hline Carter and Stone (2015) & Democracy dummy & Teorell et al. (2013) \\
& Donor GDP per capita & Heston et al. (2012) \\
& Recipient GDP per capita & Heston et al. (2012) \\
& Same political color & Beck et al. (2001) \\
\hline \hline
\end{tabular}


TABLE A-7

Granger Causality

\begin{tabular}{|c|c|c|c|}
\hline & $\overline{\text { Depend }}$ & it variables: & nent Change \\
\hline & (1) & (2) & (3) \\
\hline Lagged ODA & $0.0006^{*}$ & 0.0003 & $0.0005^{*}$ \\
\hline & $(0.0004)$ & $(0.0004)$ & $(0.0003)$ \\
\hline Recipient change & & $-0.0033^{*}$ & \\
\hline & & $(0.0020)$ & \\
\hline Donor change & & $-0.0037^{* *}$ & \\
\hline & & $(0.0016)$ & \\
\hline Recipient change $*$ lagged ODA & & 0.0004 & 0.0000 \\
\hline & & $(0.0006)$ & $(0.0003)$ \\
\hline Donor change $*$ lagged ODA & & $0.0011^{* *}$ & -0.0004 \\
\hline & & $(0.0005)$ & $(0.0003)$ \\
\hline Last year alignment & $-0.8379 * * *$ & $-0.8378^{* * *}$ & $-0.8713^{* * *}$ \\
\hline & $(0.0218)$ & $(0.0218)$ & $(0.0358)$ \\
\hline Past mean alignment & $0.5221^{* * *}$ & $0.5224^{* * *}$ & $0.2101 * * *$ \\
\hline & $(0.0200)$ & $(0.0200)$ & $(0.0238)$ \\
\hline$\overline{\text { Donor GDP }(\log )}$ & -0.0109 & -0.0090 & \\
\hline & $(0.0094)$ & $(0.0095)$ & \\
\hline Recipient GDP (log) & -0.0002 & -0.0004 & \\
\hline & $(0.0023)$ & $(0.0024)$ & \\
\hline Donor population (log) & $-0.2600 * * *$ & $-0.2617 * * *$ & \\
\hline & $(0.0202)$ & $(0.0201)$ & \\
\hline Recipient population (log) & 0.0014 & 0.0012 & \\
\hline & $(0.0062)$ & $(0.0062)$ & \\
\hline Adjusted R-squared & 0.565 & 0.566 & 0.891 \\
\hline Fixed Effects & $\mathrm{DR}, \mathrm{Y}$ & $\mathrm{DR}, \mathrm{Y}$ & DR,DY,RY \\
\hline Obs & 16337 & 16337 & 17858 \\
\hline Dyads & 662 & 662 & 673 \\
\hline
\end{tabular}

Robust standard errors in parentheses, clustered on donor-recipient dyad.

Fixed effects: donor-recipient (DR), year (Y), recipient-year (RY), donor-year (DY)

Significance levels: ${ }^{* * *} \mathrm{p}<0.01,{ }^{* *} \mathrm{p}<0.05,{ }^{*} \mathrm{p}<0.1$. 